\title{
Food Abundance and Violent Conflict in Africa*
}

\author{
Ore Koren ${ }^{\dagger}$
}

December 31, 2017

\begin{abstract}
Scholars debate whether climate change has a consistent effect on the likelihood of armed conflict in Africa. One major pathway by which climatic variability is hypothesized to increase conflict is by decreasing food availability. However, limitations on food access at both the local and national level in many developing African countries force most armed groups and communities to depend on locally produced food. These actors are therefore likely to use violence to establish control over more food resources or be stationed where more food is available, suggesting that food abundance might also be driving conflict. The present study employs novel data on wheat and maize yields in Africa measured at the very local level to empirically evaluate this hypothesis on a highly disaggregated conflict indicator. To account for the endogenous relationship between conflict and food production, average local levels of drought are used as an instrument. The findings show that, contrary to previous expectations, conflict is driven by higher yields, on average, and not by scarcity.
\end{abstract}

\section{Forthcoming in the American Journal of Agricultural Economics}

Keywords: FOOD SECURITY; CIVIL WAR; RESOURCE SCARCITY; VIOLENT CONFLICT; INSTRUMENTAL VARIABLE

JEL Codes: D74, Q11, Q18

${ }^{*}$ The author would like to thank Marc Bellemare, Ben Bagozzi, Peder Engstrom, Navin Ramankutty, Deepak Ray, the $A J A E$ editorial team (and Travis Lybbert in particular), as well as three anonymous reviewers, for their helpful comments and suggestions. This article was supported by a Jennings Randolph Peace Scholar Award from the United States Institute of Peace. The views expressed in this article are those of the author and do not necessarily reflect the views of the U.S. Institute of Peace.

${ }^{\dagger}$ Department of Political Science, University of Minnesota, Minneapolis, MN, 55455 and the Dickey Center for International Understanding, Dartmouth College, Hanover NH, 03755. Email: Koren044@umn.edu. 
A growing number of studies on environmental stressors and conflict posit that future wars will be fought over diminishing resources (Burke et al., 2009; Maystadt and Ecker, 2014; Miguel, Satyanath, and Sergenti, 2004). These studies draw links between environmental conditions, such as variations in temperature and precipitation, and civil war, hypothesizing that these factors operate, among others, through food security mechanisms. By and large, the emphasis is on food scarcities, namely that rising temperature and droughts reduce the amount of food resources available locally, which in turn forces actors to obtain access to food via violent means. For instance, in their analysis of the relationship between climate variability and conflict in Sub-Saharan Africa, Burke et al. find that "[t]emperature variables are strongly related to conflict incidence over our historical panel" (2009). They further hypothesize that, "[t]emperature can affect agricultural yields both through increases in crop evapotranspiration (and hence heightened water stress in the absence of irrigation) and through accelerated crop development...reducing African staple crop yields by $10 \%-30 \%$ per oC of warming" (Burke et al., 2009). Somewhat more cautiously, O'Loughlin et al. note that, "the positive association between instability and temperature may result from the harmful effects of high temperatures on food products such as maize" (2012).

The Malthusian notion that food scarcities increase the likelihood of conflict is not a recent one, although it has received increased attention over the last four decades (e.g., Homer-Dixon, 1998). In contrast, however, an impressive body of research draws linkages between the abundance of natural resources and conflict (e.g., Bannon and Collier, 2003; Adhvaryu et al., 2017; Blattman and Miguel, 2010). Food is not only a renewable natural resource; it is crucial to maintaining the daily life and activities of a group, be it a military battalion, a rebel contingent, or a rural community. With a large number of studies on social unrest emphasizing the importance of food security (Messer, 2009; Bellemare, 2015), it thus appears plausible that variations in local crop productivity affect past and future conflict risk. Indeed, recent research lends support to this argument. For instance, Crost and Felter (2016) show that rebels benefit from higher food crop prices, which allow them 
to expand territorial control and even establish local monopoly on violence. Despite this and other (e.g., Koren and Bagozzi, 2016), important evidence, however, to date few studies have explicitly considered the role of food and its exact effects on conflict, or attempted to evaluate how food resources shape regional and continental conflict patterns over time.

One challenge in evaluating staple crop yields' role in driving conflict is that local food productivity variables are inherently endogenous; food output can influence the propensity of violence, but the associated feedback effects from conflict can in turn influence food output (Homer-Dixon, 1998; Messer, 2009). To address this concern, the local staple crop yield indicators used here are instrumented using drought intensity levels, which — as recent studies posited - can influence conflict through food production. The causal relationship between local food production and violent conflict is thus identified using this climatic variable (Miguel, Satyanath, and Sergenti, 2004). It is important to stress that previous research has suggested that rainfall variations might be not be an ideal instrument of income shocks (Sarsons, 2015). While the argument developed here does not necessarily equate local yields with income, I address this concern both theoretically — by discussing some distinctions of African agriculture systems - and empirically, by showing that my drought-based instrumental variable is at least "plausibly exogenous" (Conley, Hansen, and Rossi, 2012).

By relying on said approach, this study provides quantitative evidence linking past internal armed conflict incidence to food yields at the very local level while incorporating variations in climatic trends, specifically droughts. Using $0.5 \circ$ grid cells $(10,674$ cells for Africa) (Tollefsen et al., 2012), the influence of annual local wheat and maize yields (Ray et al., 2012) on violence is estimated using ordinary least squares (OLS) and two-stage least squares (2SLS) regressions with grid-cell (i.e., unit of analysis) fixed effects. Conflict measures were obtained from the Armed Conflict Location and Event Dataset (ACLED) Version 6, which provides exceptional disaggregated coverage of political violence in Africa at the very local level (Raleigh et al., 2010). Unlike previous studies, which employ only climaterelated variables, focus on specific countries, or employ only binary indicators of conflict 
(Burke et al., 2009; Maystadt and Ecker, 2014; Koren and Bagozzi, 2016; O'Loughlin et al., 2012), this study relies on sub-national analysis of the annual effect of local food crop production in Africa on continuous measures of conflict within all $0.5 \circ$ grid cell for the years $1998-2008 .^{1}$

The findings presented here contribute significantly to our understanding of the relationship between food security, violent conflict, inequality, and environmental variability. The estimation procedure accommodates both the non-random assignment of observations and the possible concurrent relationship between climate, food production, and conflict. Overall, the empirical models provide new and nuanced evidence that locally grown food resources have a particularly strong influence on the frequency of conflict in Africa. In the IV models, where the effect of food resources is exogenized with respect to conflict, higher levels of food crop yields are shown to have a substantive effect on violent conflict, all else equal.

These findings challenge the notion that rising food scarcities increase conflict simply by forcing communities and armed groups to compete over a shrinking pool of food resources. Rather, empirical evidence suggests that - on average — violent conflict is not the direct result of food scarcity, but of abundance; areas with more food resources are more valued by different actors, and as a result attract more conflict. Moreover, these associations are robust to a variety of alternative explanatory mechanisms and specifications. The relationships between climatic variability, food, and violence are therefore complex and warrant careful interpretation.

\section{Staple Crop Yields and Local Conflict}

The linkage between conflict and food resources is not a recent phenomenon, engendered by climate change, but rather - in many parts of the world - a persistent historical occurrence. Throughout history, armies and militias living off the land were a regular characteristic of warfare. In ancient and medieval times, before the development of modern logistic support technologies, living off the land, foraging, and relying on the local population was a mili- 
tary necessity. Although the utilization of logistic supply chains has significantly reduced the need of modern militaries to rely on local populations for support, the bureaucratic and economic capabilities required to maintain such systems has ensured that the vast majority of armed groups in Africa lack regular support (Koren and Bagozzi, 2016). Indeed, a detailed background discussion of relationships between food resources and conflict in Africa as well as food-related vulnerabilities - provided in the online appendix due to space constraints - shows that these issues strongly impact the behavior of different armed actors in contemporary wars.

When discussing conflict over food resources, it is important to distinguish between four different categories, each with different motivations to initiate food-related conflicts, or to move into areas with more food during times of ongoing war. The first category includes official military and auxiliary state forces that do not receive (regular) support from the state, a fact which distinguishes them from other, better organized state forces. This category includes most official state forces in Africa (Koren and Bagozzi, 2016), as well as political militias. Indeed, numerous militia groups such as the janjaweed in Sudan or the interahamwe in Rwanda were especially likely to be sent to pray upon the local population, sometimes with logistic support being withdrawn from them intentionally to push them toward violent appropriations of food resources (Koren and Bagozzi, 2017). Unsupported state actors are thus likely not only to initiate conflict in areas with abundant food resource, but also gravitate toward these areas in search of necessary food support during times of war.

The second category of actors includes all rebel groups and similar nonstate actors operating against the government. These groups might attack areas with more food in order to possess these resources not only to support themselves or challenge state strongholds, but also to exploit local food resources for profit (Crost and Felter, 2016), which sometimes results with high levels of civilian victimization (Koren and Bagozzi, 2017). For instance, in Uganda, rebels are likely to appropriate and kill profitable cattle, leading to a shift in local populations' agricultural portfolios (Rockmore, 2012). Similarly, the Islamic State in Syria 
and Iraq (ISIS) fought to establish and maintain control over fertile agricultural areas due to the group's reliance on agricultural income (Jaafar and Woertz, 2016).

The third category covers militias and civil defense forces representing agriculturalist communities in rural regions. The agriculturalist lifestyle is more characteristic of areas where access to water resources is relatively stable, allowing these communities to grow crops for consumption and to be sold locally (O'Loughlin et al., 2012). Individuals and groups in these localities thus live a stationary lifestyle, and procure livestock mostly as a means of wealth accumulation (i.e., as an equivalent of a savings account) (Rockmore, 2012; Roncoli, Ingram, and Kirshen, 2001). In many countries these communities are less likely to be defended by the state due to the costs involved with sending and supporting armed groups. This in turn means that property rights are rarely enforced (Barrett, 2010), pushing many of these communities to resort to self-help. Such self-defense militias can be used not only to defend against potential raids, but also to attack neighboring communities in order to establish control over more arable land and food resources. Indeed, this last point is supported by ample anecdotal evidence, as shown in the online appendix.

The fourth category includes all militias representing pastoralist communities. Pastoralists are highly mobile groups that live in mostly arid regions. As a result, these groups are forced to rely on mobile livestock, especially cattle, rather than on crops, meaning that in this case owning cattle is not a luxury but rather a necessity dictated by their (semi-)nomadic lifestyle (Lybbert et al., 2007). Pastoralists have been at the heart of many previous studies connecting food resources to conflict, with some associating increases in precipitation with higher frequencies of raids (e.g., Adano et al., 2012; Butler and Gates, 2012), while others showing the opposite relationship (O'Loughlin et al., 2012; Maystadt and Ecker, 2014). In many cases, regional narratives emphasize how the prevalence of violent conflict is shaped by local conditions such as the precedence of civil war, which floods the region with firearms (Koren and Bagozzi, 2017), or the collapse of state authority, especially if external actors move into the vacuum and fund raids (Rockmore, 2012). Pastoralist militias might there- 
fore both raid other pastroalists in order to replenish their herds, and attack agriculturalist communities in order to both steal livestock and obtain food crops, which-due to their mobile lifestyle and the arid regions where they reside - these groups are generally incapable of growing independently.

All four actor categories, which - it is important to acknowledge - might exhibit significant overlap, have different motivations to fight over food resources. In the first two cases, given that troops are frequently mobile rather than stationary, they do not have the ability to grow food for personal consumption, and as a result must rely on food grown locally in the region in which they operate (Koren and Bagozzi, 2016). Agricultural land can be owned by local civilians who grow food for personal consumption only or by larger producers who grow food for trade, both internationally and domestically. Especially in regions without developed infrastructure and where mobilizing food resources or appropriating food aid is less possible, both government and rebel troops are forced to move into areas that offer access to food in order to support their operations. These limitations intensify the incentives for troops to seek out the few remaining areas that do have high food access for sustenance, and potentially also for rent-extraction (Jaafar and Woertz, 2016; Crost and Felter, 2016).

In the latter two cases, while agriculturalist and pastoral communities can produce food for personal consumption, they are also under a constant threat of experiencing acute food insecurity (see online appendix). The eruption of a disease or the onset of drought can suddenly kill crops and decimate herds, placing these communities at the sudden and immediate risk of starvation. Without government support or other safety nets that can mitigate the effects of these unexpected shortages, acute food insecurity is a Damocles Sword over the heads of these groups (Barrett, 2010). For example, during the drought in Burkina Faso, "farmers strove to minimize cash investments in agriculture, but in some cases they were unable to do so because many had consumed all their seed before planting" (Roncoli, Ingram, and Kirshen, 2001, 128). Such shocks jeopardize immediate food security; assuming the community survives this adverse period, it should be able to restore food supply levels. This 
suggests that cooperation might emerge as a preferred strategy in these contexts (Adano et al., 2012; Toft, 2006; Butler and Gates, 2012). However, to increase overall resilience, improve capabilities, and be better prepared to the brutal effect of shocks, such groups will be expected to increase competition during periods of abundance.

Without the ability to purchase drought-resistant seeds or livestock, and without government or international support - which in many cases cannot arrive in time or be received by those who need it - that provides safety net against sudden shocks, the only alternative to free market or aid solutions is to obtain food using violent means. Moreover, the tendency for conflict might also be affected by population growth (Homer-Dixon, 1998) or migration (Dell, Jones, and Olken, 2014), which increase the pressure to secure more resources just to keep the same level of sustenance, leading to a zero-sum, "Red Queen" scenario. ${ }^{2}$ To increase overall resilience, communities must obtain the necessary access to enough food resources during periods of plenty, when more assets could be mustered and when time horizons in respect to the competition over food are relatively long, i.e., actors perceive that more resources will make them more resilient in the future. This directly relates to the notion of time horizons in interstate war, as put by Toft: "if both actors discount the present but see their fate provided for in the future, then violence is likely" while "[i]f both actors discount the future highly, then violence is unlikely" $(2006,56)$.

Finally, it is important to emphasize that while conflict frequency might increase with higher productivity, food is not always necessarily the cause. For instance, government or rebel troops might be stationed in more fertile areas in order to protect these areas or to support themselves. Consequently, other armed actors seeking to attack enemy strongholds will move into these areas not to obtain food resources, but simply because these regions are likely to offer a valuable target. In these contexts, the impact of food resources is indirect; a military base might have been formed in this particular region to protect local food resources or simply because support is more likely there, and fighting arose as enemy forces attacked this base. Moreover, while securing food resources might be a direct cause of armed conflict 
in some cases, conflict - especially full-scale civil war-is frequently the result of political and socioeconomic issues (Fearon and Laitin, 2003). In this context, troops gravitate into areas with more food resources during ongoing war to secure food or prevent these resources from being consumed by the enemy. Therefore, while I make the argument that conflict concentrates in areas with high staple crop yields, I also recognize that groups do not fight necessarily over these resources; locations with more food resources might simply attract and sustain a large portion of ongoing violence.

Whether competition over food resources is the direct cause of conflict, or whether it directly or indirectly fuels ongoing violence, in contrast to some previous studies of the climate-conflict nexus (Burke et al., 2009; O'Loughlin et al., 2012; Maystadt and Ecker, 2014) the expectation here is that conflict should be positively associated with more food resources, all else equal. However, although multiple studies have suggested that such positive associations exist (e.g., Koren and Bagozzi, 2016; Adano et al., 2012; Butler and Gates, 2012), making a causal statement with respect to food resources is more challenging because, unlike temperature or precipitation, at the local level, food crops are likely to have an endogenous relationship with conflict. In other words, just as higher local food outputs can cause conflict, conflict can destroy crops and reduce yields.

For instance, as Messer argues, "[f]ood poverty may be exacerbated as violence disrupts migratory labor and remittance patterns over wide regions, as has been the case across multiple African areas, also Afghanistan and Iraq, whose violence, and interruptions to livelihood and security, impact neighboring countries" $(2009,15)$. Violent conflict can destroy infrastructure, displace large populations, and increase population pressures via movement of different groups and troops into the region (Koren and Bagozzi, 2017). Moreover, food insecurity can be used as a weapon of conflict in-and-of itself, as adversaries deliberately starve opponents into submission by siege or destruction of crops, livestock, and markets, and divert food relief from intended beneficiaries to armed groups and their supporters. Indeed, research into the impact of conflict on food choices found significant changes in livestock 
and crop growing patters in Uganda (Rockmore, 2012) and Colombia (Arias, Londoño, and Zambrano, 2017). Establishing the causal effect of food on conflict - or come as close to it as possible when observational data are concerned - necessitates a fitting identification strategy and effective data that allow the researcher to isolate the causal arrow flowing from food resources to conflict rather than the other way around.

\section{Data and Methods}

This section discusses the data to be analyzed, the equations to be estimated and the identification strategy to be used to establish the causal impact of food resources on armed conflict.

\section{Data}

For Africa, a grid cell sample encompassing 11 years of data from 1998 to 2008 is used to evaluate the relationship between local food crop yields and violent conflict. The geolocated data used for this analysis were obtained from the PRIO-Grid dataset (Tollefsen et al., 2012). The PRIO-Grid dataset measures a variety of spatial data at the 0.5 o resolution, or a geographic squared "cell" of roughly $55 \times 55$ kilometers at the equator (3025 square kilometers area), which decreases with higher latitudes. This dataset thereby allows one to capture the variation of specific geographic and economic phenomena globally (excluding oceans, Antarctica, and the Arctic) at the very local level. All variables were aggregated to the same grid level and integrated into this dataset for the years analyzed.

The dependent conflict variable was obtained from the ACLED Version 6 dataset and measures all incidents of political violence (including those that ended without casualties), with a focus on civil and communal conflicts, violence against civilians, remote violence, rioting and protesting that occurred both within and outside the civil war context (Raleigh et al., 2010). The actors covered by this dataset are official state forces, rebels, political militias, ethnic and tribal militias, protesters, and rioters, which means that more than any other available dataset, the ACLED Version 6 data correspond directly to the different actor 
categories discussed in the previous section. The ACLED dataset provides information on geographic specificity, i.e., whether an incident was coded at the village/town, district, or province level. To ensure comparability across different cases and variables, I analyze only events coded as occurring at the village/town level, which most closely correspond to my grid-cell level of analysis, and aggregate these incidents to the annual $0.5 \circ$ grid level.

The resulting conflict indicator is therefore defined inclusively as the total number of political violence incidents among and between different state and non-state actors within a given cell during a given year coded by the ACLED dataset. This indicator captures many nuances of political violence - including events that ended without casualties, such as strategic developments - and hence provides an improvement over other studies that employ binary indicators of conflict or focus exclusively on the state vs. rebel logic. Additionally, and again in line with the argument presented above, these data capture both instances of conflict onset and violence occurring as part of ongoing campaigns. For summary purposes, histograms and averaged values by grid cell of conflict are plotted for the 1998-2008 period in Figures A.1 and A.5, respectively, online appendix.

The effect of local food availability on the number of conflict events is evaluated using the annual local productivity of wheat and maize - two cereals that together compose the lion's share of all staple crops consumed in African households (FAO, 2016). These continuous wheat yield and maize yield indicators measure average annual levels of wheat and maize productivity at the highly localized, $\sim 0.08 \circ$ grid level, or approximately $9 \mathrm{~km} \times 9 \mathrm{~km}$ at the equator (Ray et al., 2012). ${ }^{3}$

To identify local areas where cropland is grown, Ray et al. (2012) relied on an earlier high resolution geospatial global cropland map for year 2000 created by Ramankutty et al. (2008). Ramankutty et al. (2008) utilized two sources of data to create their map. The first source were global satellite-based land cover data obtained from two previous datasets, BU-MODIS and GLC2000 (Ramankutty et al., 2008, 7-8). The second source were national and subnational census data on cropland area and food inventories. The authors then used 
regression techniques to train the satellite land cover data against the census data. The resulting estimates along with the satellite data allowed Ramankutty et al. (2008) to then map cropland areas at the high-resolution 5 minute $(\sim 0.08 \circ)$ level. In the second step, Ramankutty et al. (2008, 11-12) further adjust their high-resolution maps, scaling up or down all pixels within an administrative unit to exactly match the census data.

To interpolate their time-varying measure of crop-specific area and yield by $0.08 \circ$ grids for wheat and maize, Ray et al. (2012) then expanded the dataset developed by Ramankutty et al. (2008) in two steps. First, Ray et al. (2012, Supplementary Information, 6-12) collected an exceptionally large number of datasets crop area and yields at the subnational and national level, going back to 1961. The average number of census observations over the 1961-2008 period was 600,000 per crop, although the number of observations varied geographically. ${ }^{4}$

Ray et al. (2012) then use the high-resolution cropland map created by Ramankutty et al. (2008) as a spatial reference to disaggregate wheat and maize area and yield data within each administrative unit. The grid of staple crop yields was created "by disaggregating the yield from the smallest political unit with available data in the agricultural inventory by distributing the inventory data for each administrative unit uniformly to each pixel [i.e., 0.08 o grid] within that administrative unit" (Monfreda, Ramankutty, and Foley, 2008, 10). For wheat and maize yields, the process developed by Monfreda, Ramankutty, and Foley (2008) was repeated annually over the 1961-2008 period (Ray et al., 2012, Supplementary Information, 11-12). The crop area in each 0.08 o grid of the final map was set to zero when no reference to a crop existed in the inventory data. Information on these missing points was then interpolated from the latest five years if at higher administrative units crops reports were present (Ray et al., 2012, Supplementary Information, 12). ${ }^{5}$

It is important to note that data quality might be poor in some countries, sometimes due to ongoing political strife, which means that some countries do not provide annual reports. These issues, however, are unlikely to affect the specific data used here. First, the geospatial 
and temporal interpolation of missing data as discussed above should help ameliorate some missing-ness issues resulting from ongoing strife. Moreover, the authors created a useful metric (presented in Ray et al., 2012, Supplementary Information, 12) to evaluate overall data quality for each political unit. As shown in Ray et al. (2012, Supplementary Information, 1), the data quality for Africa is generally high at the reported administrative level (averaging within the top 90th percentile) and - with a data quality level that is nearly identical to North America's - is better than any other world region. It is important to emphasize, however, that the vast majority of crop output data on Africa were available only at the national level. Thus, for most African countries Ray et al. (2012) interpolate localized changes in wheat and maize yields within each particular $0.08 \circ$ grid based on national averages, which is less than ideal.

These limitations notwithstanding, the resulting wheat yield and maize yield indicators provide "a dramatically improved understanding of crop yield and area changes across regional and global scales, which are otherwise often obscured using only national census statistics" (Ray et al., 2012, 2), especially in world regions where subnational statistics are missing or nonexistent, such as Africa. Indeed, as highlighted by 24 food-system experts, a salient problem with current attempts to assess local food security is that, "the data collected are rarely comparable across ecological zones because of inconsistencies in methodologies or in the spatial scale at which observations are made" (Sachs et al., 2010, 558). From this perspective, the high-resolution data produced by Ray et al. (2012) provide a significantly and substantively better fit for observed local food production trends, even when compared with other high-resolution datasets such as BU-MODIS or GLC2000. Using a dataset that combines satellite-derived imagery and staple crop inventory data also allows scholars "to capitalize on whichever satellite-based land cover data set is best suited to each region," compared with the constituent datasets, which on their own would provide "reasonably good global results, but would lose accuracy in some regions" (Ramankutty et al., 2008, 10).

To ensure comparability to the other data used in this present study, both the wheat yield 
and maize yield indicators were averaged to the $0.5 \circ$ grid cell level to ensure comparability across observations. A value of one thus corresponds to a grid-cell whose total area is entirely covered by wheat or maize crops, respectively, during a given year. For summary purposes, averaged values for wheat yield and maize yield (by grid cell) are plotted for the 1998-2008 period in Figures A.6-A.7, online appendix. Additionally, the correlations between average annual wheat and maize yields, and the number of conflict events per grid cell, are plotted in Figure 1 below.

\section{Insert Figure 1 about here}

The instrument used to "exogenize" the effect of food on conflict, drought, is operationalized using a Standardized Precipitation Index (SPI) that aggregates monthly precipitation data to the cell-year level (Guttman, 1999). This SPI-based indicator classifies drought severity as the number of standard deviations below average precipitation levels in a particular grid cell during a given year. The resulting drought variable is an ordinal indicator

(it can take the values of $0,1,1.5$, and 2.5 standard deviations below the mean) providing a straightforward measure of rainfall shocks and - correspondingly - their impact on food production.

The models reported below also employ different controls. First, considering the potential impact of population pressures on food availability and the number of conflict events as raised by previous studies (e.g., Homer-Dixon, 1998), I account for population density in a given cell during a given year using the variable population (Nordhaus, 2006). This cell-level variable was originally measured for the years 1995, 2000, and 2005 and then interpolated to the yearly level using a last-value-carried-forward approach (Tollefsen et al., 2012). To control for spatial correlation, I include a binary spatial lag of the dependent variable, conflict (spatial), denoting whether any conflict events occurred in the first-order neighboring cells. I also include a one-year lag of the dependent variable, conflict (lag), to control for the temporal dependence of conflict events, alongside annual and grid cell fixed effects. 
Crucially, these variables are all measured at the grid cell, and not country, level. Furthermore, the crop yield measures used for analysis are time varying, which provides a major improvement over past studies of this sort that have favored static measures of cropland at comparable levels of geographic resolution (e.g., Koren and Bagozzi, 2016; O'Loughlin et al., 2012). Nevertheless, to account for alternative explanations (e.g., Fearon and Laitin, 2003; Bannon and Collier, 2003), several country level indicators were also included in analysis. The democracy measure is the ordinal Polity2 indicator, with higher values corresponding to more democratic regimes (Marshall, Jaggers, and Gurr, 2013). The gross domestic product (GDP) per capita measure, GDP per capita, was obtained from the World Bank (2015). Finally, a large number of alternative mechanisms are evaluated in the Competing Mechanisms section below. For summary purposes, all variables-including those used in sensitivity analyses - are reported in Table 1.

\section{Insert Table 1 about here}

\section{Identification Strategy}

Local food yields cannot be argued to be exogenous to localized conflict, because the latter might devastate infrastructure in the region and generate more population pressures (e.g., via troops moving in). This suggests that the estimates provided by OLS regressions are likely to be biased due to simultaneity between the main explanatory variable and the dependent variable. The identification strategy used in this article therefore relies on the use of an instrumental variable (IV), i.e., a variable that is correlated with food production but arguably uncorrelated with the error term of violent conflict. This framework is in line with previous studies of the relationship between agriculture and economic growth, climate, and conflict (e.g., Miguel, Satyanath, and Sergenti, 2004; Sarsons, 2015; Bellemare, 2015).

Recall that an IV must satisfy two requirements. First, it must be correlated with food production at the local level. To this extent, Table 3 shows that the instrument is not weak, excluding, perhaps, the Full specifications (Stock and Yogo, 2003). Second, the IV must only 
affect violent conflict through food production, a requirement that is also known as meeting the exclusion restriction (Angrist and Pischke, 2009).

To account for the potentially endogenous relationship and "feedback effects" between violent conflict and food production, and obtain consistent estimates, I rely on the ordinal drought indicator discussed above, which is crucially measured at the annual grid level, in a manner consistent with previous research (e.g., Miguel, Satyanath, and Sergenti, 2004; Crost and Felter, 2016). As a climatic indicator, this instrument is highly unlikely to be directly endogenous with violent conflict. At the same time, this instrument is likely to be highly correlated with local wheat and maize yields, which means that the IV models identify the true relationship between food security and conflict, conditional on droughts, and are thus preferred to their OLS counterparts. This is easily ascertained with statistical tests - in effect, tests of the null hypothesis that the instrument is weak - the results of which are shown in Table 3. Moreover, the effect of droughts on food production and on increasing food scarcities has been the tenet of previous studies of the climate-conflict nexus (e.g., O'Loughlin et al., 2012). Importantly, as discussed in the online appendix, droughts are also likely to monotonically affect food production by decreasing yields everywhere they impact.

It is important to recognize, however, that previous research suggested that - in some situations - rainfall shocks might not necessarily pass the exclusion restriction. Sarsons (2015), for instance, relies on information on dam construction in India to illustrate that while income in downstream areas is less sensitive to rainfall fluctuations, rainfall shocks remain a strong predictor of riots in these contexts. As this is not a trivial concern, I address it both theoretically and empirically. First, note that, perhaps even more so than in India (the focus of Sarson's study), most agriculture in Africa (especially Sub-Saharan Africa) during the ten-year period analyzed here depended almost exclusively on rainfall (FAO, 2008; Kastner et al., 2012). As a result of this high dependence on precipitation, the amount of land required to produce food in these regions actually increased over time, as opposed to Asia, where researchers observed notable decreases in the amount of land required to support a 
certain number of people (Kastner et al., 2012).

These context-specific differences suggest that, at least from a theoretical perspective, the use of drought as an instrument for the impact of local food yields on conflict in Africa is defensible. Moreover, rainfall can impact conflict through both positive and negative deviations from the mean, with too much precipitation causing overly high levels of soil moisture, thus increasing the risk of crop disease (FAO, 2008). This suggests that the impact of being located down- vs. upstream from irrigation dams as identified by Sarsons (2015) is more likely during positive rainfall shocks. To help accounting for this concern, I restrict my drought instrument to focus only on negative rainfall shocks as discussed above. ${ }^{6}$

I also address this concern empirically. First, note that Sarsons shows that the violation of the exclusion restriction for rainfall-based instruments is the results of location, specifically, rather than issues such as conflict spillovers or migration $(2015,67-68)$. This in contrast to the latter's impact of economy-wide effects at the country level, where these and other channels might be at play (Carleton and Hsiang, 2016; Dell, Jones, and Olken, 2014). To account for constant factors such as geographic locations at the highly disaggregated geospatial level, I include fixed effects for each grid-cell in my sample and cluster standard errors at a similar level to address heterogeneities. Considering the relatively small size of this unit of analysis ( $0.5 \times 0.5$ grid) compared with, say, the province or even district levels, this approach should help fix much of the geo-spatial variance within my sample, including variance resulting from upstream vs. downstream locations.

More importantly, however, I rely on the method developed by Conley, Hansen, and Rossi (2012) to allow for departures from the exclusion restriction, i.e., allowing the IV to have some direct effect on conflict that is not exclusively restricted to food productivity, to show that this IV is still "plausibly exogenous." Briefly, Conley, Hansen, and Rossi (2012) identify that, often, the exclusion restriction is suspect because many IVs are endogenous to some extent. To test how much a given IV violates the exclusion restriction, they accordingly present several practical methods for performing inference while relaxing the exclusion restriction 
and showing that an IV can pass a certain threshold of endogeneity but still remain exogenous enough for the purpose of inference. Indeed, as shown in Table 4 and discussed in more detail below, the IV drought survives local-to-zero approximation tests for "plausible exogeneity," suggesting that - empirically - the use of this IV is defensible (Conley, Hansen, and Rossi, 2012).

If the instrument is valid and effectively exogenizes food production relative to conflict, then the coefficients for wheat yield and maize yield are the weighted average, covariate specific local average treatment effects (hereon, "average LATE") of food production on violent conflict, i.e., the increase in the extent of violent conflict (as measured by the continuous dependent variable) due to food production in those grid cells and years where droughts induce a change in maize and wheat yields, accounting for other covariates (Angrist and Pischke, 2009, 130). Hence, the relationship between food production and conflict at the local level is identified using the following two-equation system in the IV models:

$$
\begin{aligned}
& y_{i t}=\alpha_{1}+\beta_{1 f} \hat{f}_{i t}+\beta_{1 y} y_{i, t-1}+\beta_{1 s} y_{s t}+\beta_{1 X} X_{i t}+\mathbf{\Phi}_{\mathbf{1 i}}+\mathbf{\Psi}_{\mathbf{1 t}}+\epsilon_{1 i t} \\
& f_{i t}=\alpha_{2}+\beta_{2 c} c_{i t}+\beta_{2 y} y_{i, t-1}+\beta_{2 s} y_{s t}+\beta_{2 X} X_{i t}+\boldsymbol{\Phi}_{\mathbf{2 i}}+\boldsymbol{\Psi}_{\mathbf{2 t}}+\nu_{2 i t}
\end{aligned}
$$

Where $y_{i t}$ is a vector of violent conflict incidents by grid cell for each year; $y_{i, t-1}$ is the temporal lag of the dependent variable; $y_{s t}$ denotes whether conflict occurred in neighboring cells or not each year; $X_{i t}$ is a matrix of control variables; $\boldsymbol{\Phi}_{\mathbf{i}}$ are $\boldsymbol{\Psi}_{\mathbf{t}}$ are fixed effects by grid cell and year, respectively; $\alpha$ are the constants for each equation; ${ }^{7} \epsilon_{1 i t}$ is the error term for the second stage regression and $\nu_{2 i t}$ is the error term of the first stage regression. In this system, $\hat{f}_{i t}$ is the instrumented effect of wheat or maize yields as estimated by equation 2 , i.e., the increase in the extent of violent conflict (as measured by the dependent variable) due to wheat or maize yields in grid cells and years where drought, captured by the vector 
$c_{i t}$, induces a change in crop yields. As the data for some variables are duplicated over time, grid cell-clustered standard errors for all models are used to assess statistical significance.

To treat the observed quantities on all variables for each cell as non-random, fixed effects for each grid cell were included in all models; and fixed effects for each year covered in the data (1998-2008) were also included to account for potential time dependencies. The use of unit of analysis fixed effects - i.e., including binary variables for the units of analysis, in this case grid cells, to capture observed and unobserved influences on an outcome of interest (the frequency of conflict in this case) that are constant over time - is a well-established statistical procedure for identifying causal relationships (Angrist and Pischke, 2009). This approach, combined with the use of a valid instrument to "exogenize" the effects of the endogenous explanatory indicators, allows the IV models to isolate localized food production effects and make the case for a consistently significant higher risk of conflict with increased yields.

\section{Results}

To evaluate the effect of local food yields on conflict I estimate two separate specifications for each crop. These models build on the availability and access aspects of food security as described by Barrett, two concepts that are "inherently hierarchical, with availability necessary but not sufficient to ensure access" (2010, 825). Considering that food availability is "typically measured in daily calories per person" (Barrett, 2010, 825), the Baseline - or availability - model includes only food yields, i.e. the total amount of wheat or maize available in a given grid cell during a given year (exogenized by drought in the IV models) in addition to grid cell and year fixed effects to account for constant observed and unobserved confounders. Building on the definition of food access as "the range of food choices open to the person(s), given their income, prevailing prices, and formal or informal safety net arrangements through which they can access food" (Barrett, 2010, 825), the Full specifications incorporate a variety of controls (discussed in the previous section) alongside food yields to account for the impact of salient political and socioeconomic conditions. 
Table 2 reports the coefficient estimates of four OLS models that each assesses the likelihood of cell-year conflict in Africa. The effect of these variables is then compared to their average LATE in Table 3. Due to space constraints, the direct impact of drought on conflict and the first-stage regression estimates for the IV models are reported in Tables A.2 and A.3, respectively, online appendix. The hypothesized relationship between food yields and conflict is evaluated against benchmark explanations of conflict risk: socioeconomic and po-

litical indicators, and conflict history (Fearon and Laitin, 2003; Bannon and Collier, 2003). The linear effect of wheat and maize yields on conflict without accounting for endogeneity concerns is estimated in Models 1-4. The exogenized effect of these indicators on localized conflict is then estimated in a series of IV regressions in Models 1E-4E.

\section{Insert Table 2 about here}

\section{Insert Table 3 about here}

In Model 1, wheat yield has a negative but statistically insignificant effect on conflict. However, by destroying infrastructure, causing civilian producers to flee, or through "scorched earth" tactics, conflict might also negatively impact food production. This coefficient might thus reflect a reversed relationship, which obscures the true effect of local yields on violence. Model 1E, where the effect of local food production with respect to conflict is instrumented using drought, accounts for this likely scenario. Here, wheat yield is positively and significantly associated with the incidence of conflict, which suggests that conditional on average conflict in a given cell, localized conflicts arise more often during years of high yields.

The Full (or "access") specification presented in Models 2 and $2 \mathrm{E}$ include a variety of controls to show that these results are indeed consistent with the addition of a large number of socioeconomic, political, and spatial-temporal confounders. Here, the effects of GDP per capita, democratization levels, population density, as well as spatial and temporal conflict dependencies are evaluated, in addition to the wheat yield variable included in Models 1 and 1E. While the effect of within-grid cell wheat production on violent conflict in Model 2 is again 
statistically insignificant, the instrumented effect of wheat yield is positive and statistically significant in Model 2E, even with the inclusion of these alternative explanations. This again confirms the argument that, on average, years with higher yields increase the frequency of conflict within a given cell during a given year.

Models 3-4 and 3E-4E estimate the same specifications, this time using maize as an approximation of local food availability. The effect of maize yields is negative and significant in the Baseline and Full models for the OLS regressions. Yet, in the IV models maize yield is consistently positive and significant across both the Baseline and Full specifications. These findings again support the hypothesis that conflict within a given grid cell is likely-on average - to arise during years with higher yields, when the conditional impact of droughts on annual crop productivity by grid cell is estimated. Moreover, diagnostic regressions of the instrument drought on the endogenous yield variables presented in Table A.3, online appendix, are significant, suggesting that the IV estimates are indeed informative (Angrist and Pischke, 2009). ${ }^{8}$

The estimated impact of staple crop yields on local conflict frequency is sizable: focusing on Model 1E as the benchmark, the average marginal effect for wheat yield indicates that a $0 \%$ to $100 \%$ change in wheat yields increases the predicted number of conflict events in a given grid cell during a given year by approximately 75 incidents. This suggests that for a mere $1 \%$ increase in wheat yield, the predicted number of conflict events by cell increases by approximately 0.75 incidents. Considering that the average number of conflict events for an average grid cell, during a given year for the entire 1998-2008 period, is 0.228 , this effect is substantive.

More broadly, endogenous variable tests are significant, suggesting that endogeneity between the dependent and explanatory variables likely exists and thus supporting the use of IV models. In Models $1 \mathrm{E}$ and $3 \mathrm{E}$ the F-statistic for a weak instrument far exceeds the threshold of 10 (Stock and Yogo, 2003) for an IV not to be considered weak, while in Models $2 \mathrm{E}$ and $4 \mathrm{E}$ the instrument is borderline weak when clustered standard errors are used, 
suggesting that this model might be marginally biased toward OLS estimates. Finally, as shown in Tables A.7-A.8, online appendix, the results are consistent when each control is added sequentially to arrive at the Full specifications. Thus, this analytical framework and the consistency of the results across different specifications suggest that positive local food yields have a strong impact on localized conflict in Africa. This effect is not unique to one crop, but rather characterizes at least two distinct staple foods. Crucially, Models $2 \mathrm{E}$ and $4 \mathrm{E}$ clearly show that this finding is not the result of local population densities, higher levels of state presence, or economic development, all of which are controlled for by these models.

\section{Sensitivity Analyses and Competing Mechanisms}

Below I evaluate the sensitivity of my findings to the plausible exogeneity assumption, modeling choices, and a large number of competing mechanisms. Due to space constraints, all other sensitivity analyses, as well as all variables used in this section, are discussed in full in the online appendix and only briefly below. Additionally, to account for the varying importance of wheat and maize across different African regions, the main analyses are repeated by omitting each African sub-region from the sample at a time in Tables A.9-A.13, online appendix, to illustrate the findings' robustness to regional bias.

\section{Sensitivity Analyses}

I begin by assessing the robustness of my IV regression results to small departures from the strict exogeneity assumption required for those results to be identified. Having discussed

these issues theoretically above, I apply the method developed by Conley, Hansen, and Rossi (2012) to deal with plausibly - but not strictly-exogenous instruments. In applying this methodology, it is necessary to impose some sort of prior on said departures from strict exogeneity, with the trade-off being that the less precise the prior, the less precise the resulting models' estimates will be. I thus utilize Conley et al's intermediate local-to-zero (LTZ) method, which only requires one to impose a prior on the mean and standard deviation for the parameter measuring the magnitude of the presumed departure from strict exogeneity. 
In this case, I assume a mean of a zero (i.e., no direct effect) and a standard deviation of 0.1, thus allowing for relatively wide departures from strict exogeneity. However, the LTZ approach relies on particular specifications and a large number of computer simulations. Due to the size of my sample and the complications involved with using grid cell fixed effects under this framework, it was impossible to run LTZ models with available computer resources.

Considering these complications, each LTZ model was estimated on a collapsed sample for the entire 11-year period of analysis. In this sample, a binary indicator for drought, denoting whether a given grid cell experiences drought with one or more standard deviations below the mean of a given cell's precipitation levels, is used as an IV, while all other variables were averaged for the entire period (excluding conflict, which was summed). This time-invariant grid cell framework thus nullifies the need for grid cell fixed effects. Additionally, because the LTZ approach requires the inclusion of at least one exogenous variable alongside the endogenous one in the model, all Baseline models include population in addition to wheat yield and maize yield. Table A.4 (online appendix) replicates the main analysis on said collapsed sample to show that each food indicator's coefficient maintains roughly the same substantive size (within one order of magnitude), sign, and significance as reported in Table 3, across both the Baseline and Full specifications. The results of the Conley, Hansen, and Rossi's LTZ estimations presented in Table 4 then show that both food indicators are robust to substantive departures from the assumption of strict exogeneity of drought on conflict.

\section{Insert Table 4 about here}

Another methodological concern relates to the structure of my data, which include a large number of units, but a relatively low number of time periods. This might suggest susceptibility to estimation bias when linear fixed effect models - implying unobserved heterogeneity are used (Blundell and Bond, 1998). Additionally, the time demeaning operation of fixed

effects in these models means that the error terms of the dependent variable and its lag are correlated, causing an inconsistency in such estimator, referred to as the "Nickel Bias" 
(Blundell and Bond, 1998, 128). Although the use of standard IV regressions within paneltime-series data is a standard practice (e.g., Miguel, Satyanath, and Sergenti, 2004; Sarsons, 2015), to show that my IV model results are robust to these concerns, I additionally estimate a series of generalized method of moments (GMM) models below (Blundell and Bond, 1998).

A key assumption of these GMM models is that the necessary instruments are "internal;" that is, based on lagged values of the instrumented variable(s). The model is accordingly specified as a system of equations, one per time period, where the instruments applicable to each equation differ (in later time periods, additional lagged values of the instruments are available). With the individual fixed effects swept out, a straightforward instrumental variable estimator is available. The system GMM approach also has an advantage over firstdifferencing GMM models, as the former is much more susceptible to the aforementioned Nickel Bias effects (Blundell and Bond, 1998, 128; 138), and was hence preferred within the context of the present analysis.

Following the procedure established by Blundell and Bond (1998) for using endogenous instruments in dynamic panel data, I estimate system GMM models that rely on the past values of yields as instruments for the contemporary effect of yields on conflict. However, to further ensure that these models can claim exogeneity, and considering that the large size of the grid panel suggests a very large number of available lagged instruments and thus overfitting (Arellano, 2003; Roodman, 2009, 139-140), I rely on deeper lags of the dependent variable, in a manner suggested by past research (Arellano, 2003; Blundell and Bond, 1998; Roodman, 2009, 137). Therefore, in all models reported in Table 5 the GMM instruments are the $t-4$ and beyond lags of the dependent variable, conflict. For robustness purposes, however, Table A.5, online appendix, also reports similar models where the GMM instruments are the $t-2$ year lags and beyond of the dependent variable and the $t-1$ and beyond lags of conflict (spatial).

The results of the Blundell and Bond (1998) system GMM models presented in Table 5 show that both local yields indicators are statistically robust to departures from the 2SLS 
framework, although marginally so in the full specification of the maize yield model. While the results are not statistically weakened due to the inclusion of a large number of endogenous instruments, Sargan tests do offer evidence of over-identification, even when relying only on deep DV lags, implying that endogeneity may remain a concern within these GMM models. While this can be explained by the sheer size of the grid panel (10,674 cells), by providing an additional way of instrumenting the effect of food on conflict, these GMM models nevertheless show that the relationship between local yields is positive, which complements the IV regressions and LTZ models used previously.

\section{Insert Table 5 about here}

\section{Competing Mechanisms}

Having shown that the finding presented in Table 3 are generally robust to modeling choices, I now turn to empirically evaluating a large number alternative mechanisms that could explain the main results. Due to space constraints, these variables are discussed in detail in the online appendix.

One of the most robust explanations to the onset of conflict connects low development and economic inequalities to conflict frequency (Blattman and Miguel, 2010; Fearon and Laitin, 2003). Considering that such underdeveloped regions are also more susceptible to limitations on food access and availability (Kastner et al., 2012), low development, economic inequality, and limitations of food are likely to be highly correlated. From this perspective, grid cells with lower economic activity are likely to have more unemployment, more disadvantaged individuals, and hence suffer from more conflict, independently of variation in local yields.

To this end, Model 13 in Table 6 replicates the Full IV analysis with the inclusion of an annual cell-level economic development indicators, nighttime light, which measures annual nighttime light emissions in a given cell as a proxy of local development, as used by past studies (Koren and Sarbahi, Forthcoming). As can be observed, the variables wheat yield and maize yield maintain their sign and significance across all models, suggesting that their 
impact is not (only) the result of low development levels and inequalities.

Moreover, in addition to illustrating the validity of this mechanism by the process of elimination - i.e. by empirically accounting for a variety of alternative mechanisms - Figure 2 further highlights the interactions between economic inequality, food resources, and conflict. Here, nonparametric regression plots - which do not enforce a modeling structure on the data and hence provide a more flexible method of visualizing relationships between different factors - show the correlations of local yields and conflict in respect to economic development as approximated using nighttime light levels. As shown, conflict occurs more frequently in cells with more crop productivity but relatively low levels of economic development, wherebased on anecdotal evidence at least-limitations on food access are more likely (Roncoli, Ingram, and Kirshen, 2001).

\section{Insert Figure 2 about here}

Model 14 in Table 6 examines whether the observed effects of the crop yield variables are driven by abundance of lucrative resources such as oil and gas exports (Ross, 2011), which previous research connected to higher conflict frequency (e.g., Bannon and Collier, 2003; Blattman and Miguel, 2010). The effect of localized food production remains positive and significant in these models, suggesting that the availability of other profitable natural resources is not driving the results.

Third, some scholars have highlighted the potential effect of food imports and food aid on conflict (e.g., Bellemare, 2015; Nunn and Qian, 2014). From this perspective, higher levels of food imports and food aid might increase competition between armed groups over expropriating these resources, and hence explain the pattern observed in Table 3. To account for the impact of food and agricultural imports more broadly, as well as total aid, Model 15 includes three additional controls - food imports and agricultural imports, aid - all taken from World Bank (2015). Although the variable agricultural imports has a statistically significant effect across all models and food imports in the wheat model (aid changes its 
coefficient across the models), the inclusion of these variables does not diminish the sign and significance of wheat yield and maize yield. The impact of local food productivity on the propensity of conflict is again shown to be independent of that of other factors, in this case agricultural and aid dependencies at the national level.

Fourth, recall that my dependent variable incorporates all conflict types and related developments occurring within a given cell during a given year, with or without casualties. A competing explanation might be that the number of conflicts without casualties "inflates" the variable conflict, thus affecting the results. To address this concern, Model 16 re-estimates the Full analyses on a dependent variable that captures only violent incidents, i.e., recorded events at the village level with at least one combatant or civilian fatality (Raleigh et al., 2010). The coefficients of both wheat yield and maize yield maintain their sign, significance, and size (within one order of magnitude), suggesting that the the findings are robust to inclusion of nonviolent conflict events within the dependent variable.

Fifth, previous research has drawn strong linkages between ethnic enmities and localized political violence (e.g., Fjelde and Hultman, 2014). To evaluate whether the primary findings were the result of such ethnic enmities, Model 17 in Table 7 includes two additional controls: ethnic diversity, a count of the number of politically relevant ethnic groups settled in a particular cell during a given year (Wucherpfennig et al., 2011); and terr. change, denoting whether a new occupier was reported in a given cell (Raleigh et al., 2010). While the coefficients of both ethnic diversity and terr. change are positive and statistically significant, they do not diminish the effect of local food productivity.

Sixth, recall that my argument does not suggest that scarcity never impacts conflict, but rather that - on average - violence would be more frequent in food abundant areas. To provide a more empirically thorough evaluation of scarcity's role in driving conflict, Model 18 incorporates two additional controls, temperature and its lag (Tollefsen et al., 2012), to show that doing so does not diminish the sign or significance of wheat yield and maize yield. This, again, lends support to the argument that, at least at the local level, on average, it 
is food abundance that impacts conflict frequency. Additionally, the coefficients signs of temperature and temperature (lag) change from positive to negative as one moves from the wheat models to the maize models. Interestingly, and shown in Table A.6, online appendix, this relationship holds when the one year lag of each crop is included in the model instead of lagged temperature levels. Considering that $\mathrm{R}^{2}$ scores suggest that both wheat models are preferred to their maize counterparts, it might be that conflict is more frequent in regions that previously experienced both higher yields and higher temperatures, although these results are far from definite. Alternatively, wheat might be simply more sensitive to higher temperatures.

Interestingly, when cereal and meat production indexes (obtained from FAO, 2016) are added in Models 19 and 20 (for countries and years for which information is available), the former's effect is positive and significant, while the latter's effect is negative and significant. These results can help reconcile some of this article's seemingly-counterintuitive findings with previous research that emphasizes the role of scarcity. For instance, Maystadt and Ecker (2014) find that droughts induce higher food prices, which in turn increases localized frequency of conflict. In contrast, Table 3 illustrates that when the same instruments are used for cereals, the results are the opposite. Interestingly, in both Model 19 and 20, country-level food production indexes exhibit the same relationship: cereal production has a positive and significant relationship with conflict frequency, while meat production is negative and significant. This suggests that future research should focus not necessarily on whether scarcity vs. abundance drives conflict, but rather on the distinct relationships exhibited by different food resource types with respect to conflict.

Seventh, to address the concern that rebel groups might be more dependent on locally grown food than official state forces, Model 21 in Table 8 re-estimates the Full specifications, where the dependent variable includes only conflicts waged by official state forces. In these models, the dependent variable (and its lag) were operationalized as the annual number of all conflict events - with and without fatalities - that involved official military forces in given 
grid cell. The results are robust to this choice of DV, suggesting that - as previous research (e.g., Koren and Bagozzi, 2016) shows - abundance has a noticeable impact even on regular state forces, which are generally considered better organized and well-supported.

Eighth, note that my sample includes a relatively large number of cells with zero values or missing informations, which might affect the results. To address these concerns, I first re-estimate the Full models on two subsamples that include only grid cells where some wheat or maize, respectively, are grown in Model 22. I then repeat this analysis on a subsample that includes only grid cells that experienced conflict as some point during the 1998-2008 period in Model 23. As can be observed in both sets of analyses, the coefficients of wheat yield and maize yield maintain their sign, size, and significance, suggesting that the findings are not driven by a high number of zero values or missing information on conflict events.

Ninth, considering that some studies suggest larger countries are also more likely to suffer from protracted conflict (e.g., Fearon and Laitin, 2003), Model 24 re-estimates the Full specifications on a sample consisting solely of countries whose geographic size is bellow the $75 \%$ percentile of all African countries. Again, the coefficients of wheat yield and maize yield maintain their sign, size, and significance, suggesting that the main analysis results are not driven by the inclusion of large countries in the sample.

Table 9 accounts for possible biases that might be caused by the distribution of the dependent variable or the choice of the unit of analysis. To this end, Model 25 re-estimates the full specification using a logged version of the dependent variable (and its lag) to verify that the effect of wheat yield and maize yield is not driven by the range of values on conflict ( $0 \Leftrightarrow 344$ annual incidents). Model 26 then re-estimates the Full specification on a sample where the top one percent of all values (including zero values, to make this sensitivity test even more robust) on wheat yield and maize yield was removed from each model, respectively, as to account for the effect of outliers (see also Figure A.8, online appendix).

Next, considering that political violence measured at the $0.5 \circ \mathrm{x} 0.5 \circ$ fine-scale level might exhibit higher levels of spatial and serial correlations besides the regressors in equations 1 
and 2, Model 27 re-estimates the Full IV models, where standard errors are clustered at the higher, province level of aggregation. Finally, to account for both observed and unobserved annual country-level factors, Model 28 re-estimates the Full model with the inclusion of country $\times$ year fixed effects. Note that this procedure is very likely to generate Type II errors, and indeed, the model issues a warning that the resulting standard errors are likely to be inflated, which did not happen with any of the other (numerous) models reported in the article and online appendix. Nevertheless, the results are robust to the inclusion of country $\times$ year fixed effects in the maize model, although the wheat model drops out of significance $(p=0.17)$.

Finally, recall that the drought variable used to instrument food productivity is an ordinal measure of different degrees of drought severity. To illustrate that the effect of drought as an instrument for local food yield is robust to more penalizing thresholds of negative rainfall shocks, several alternative binary IVs are used to instrument the average LATE of wheat yield and maize yield on conflict in Table 10 below.

The first alternative instrument used in Model 29, any drought, is a binary variable operationalized as grid cell years that experienced drought levels of 1 or more standard deviations below average precipitation level, zero otherwise. The instrument used in Model 30, severe drought, is a binary variable operationalized as grid-cell years that experienced drought levels of 1.5 or more standard deviations below average precipitation level, zero otherwise. The instrument used in Model 31, extreme drought, is a binary variable operationalized as grid-cell years that experienced the worst drought levels of 2.5 standard deviations below average precipitation level, zero otherwise. The sign, size, and significance of each local food yield's coefficient remains practically unchanged, even when droughts are operationalized using these different negative rainfall shock thresholds.

\section{Insert Table 6 about here}

\section{Insert Table 7 about here}




\section{Insert Table 8 about here}

\section{Insert Table 9 about here}

\section{Insert Table 10 about here}

\section{Discussion and Conclusion}

The results presented in this article suggest that agricultural regions experience relatively high levels of violent conflict that are, to a large extent, driven by the type and amount of

food resources produced there. By exploiting exogenous negative local variations in rainfall that generate local decreases in staple crop yields, this analysis advances knowledge on an important cause of violence: conflict frequency in Africa responds to positive local changes in crop productivity. These findings diverge from the current conceptualizations of this relationship in mainstream literature, which frequently attribute conflict to sudden food shortages (e.g., Burke et al., 2009; Maystadt and Ecker, 2014). This article has theorized and shown that scarcity-based explanations are insufficient in explaining localized conflict over food resources, their potential validity notwithstanding.

This, of course, does not mean that prolonged heat waves or lower yields do not impact conflict. Indeed, it might be that the findings here complement previous studies that focus on the country level (e.g., Burke et al., 2009); conflict in areas with higher yields might be more frequent in countries that are more vulnerable to climate-induced scarcities. Moreover, as shown in Table 7, different types of food resources might have diverging impacts on the probability of conflict.

Another explanation for the present analysis' findings is the possibility that different aspects of production are associated with distinct types of conflict. Models 16 (Table 6) and 21 (Table 8) presented in the Robustness section include alternative conceptualizations of conflict, but it is possible that patterns of violence might vary according to the focus on inputs or outputs of production. McGuirk and Burke (2017), for instance, identify lower 
incidence of "factor conflict" (i.e., over raw inputs) within food-producing cells with higher prices, as armed groups benefit more from harvesting crops than waging violence. However, higher prices can concurrently generate "output conflicts," as the benefits of using violence to secure food surplus outweigh decreasing wages within these areas (McGuirk and Burke, 2017, 26). While the earlier finding (regarding "factor conflict") is in line with research into how scarcity impacts armed conflict, the latter seems to confirm, at least to some extent, the present analysis. ${ }^{9}$

Future research might thus benefit from analyzing in more detail how these effects vary across different resource types, how the interactions between food abundance and climatic shocks impact conflict, and the degree and extent to which these relationships vary between different levels of analysis, e.g., the country and the district. A second direction would build on the approach used by scholars such as McGuirk and Burke (2017) and Fjelde (2015) and create localized (e.g., at the $0.5 \circ$ grid cell) measures of food inputs and outputs. Such analysis would likely benefit from using time-varying measures of crop area and yield such as the ones used here, rather than by relying on satellite images that are constant for the year 2000, as is the case with much of the previous research.

Considering the potentially grim implications of food security for conflict and instability (FAO, 2008), highlighting the peace-building challenges imposed by local food-related inequalities using a spatially disaggregated approach can be consequential. International and nongovernmental organizations can use this information to adapt field work to advance both food security and peace through developing local capacity and sustainability alongside traditional peace-building strategies. Hunger and conflict usually go hand-in-hand, but using concrete data about food productivity, the nature of the conflict, the actors and the context, can increase our understanding of how to prevent or mitigate conflict and its consequences. 


\section{Notes}

${ }^{1}$ The temporal period for which information on all variables was available. See also Adhvaryu et al. (2017) for a study that relies on similar resolution levels for analyzing conflict across sub-Saharan Africa.

${ }^{2}$ Building on Lewis Carroll's apt description, a "Red-Queen" race is a competitive scenario, in which every actor must match or exceed the current expenditures of rivals, so that each is forced by the others to invest even more resources only to maintain the same position (Baumol, 2004, 238).

${ }^{3}$ For detailed information on the sources and methods used to compile these data, see, Monfreda, Ramankutty, and Foley (2008, 4-9), Ramankutty et al. (2008, 6-10), and Ray et al. (2012, Supplementary Information, 11-15).

${ }^{4}$ Crop inventory information became more easily available after 1990, the period analyzed here (Ray et al., 2012, Supplementary Information, 11).

${ }^{5}$ While Ray et al. (2012) also calculate changes in staple crop yield trends using categorical trend indicators, the present article relies on the raw high-resolution yield information underlying the analyses conducted in Ray et al. (2012).

${ }^{6}$ This approach also builds on Dell, Jones, and Olken, who note that, "[a] promising direction for research on droughts would construct a drought definition based solely on exogenous environmental variables such as precipitation" (2014, 755).

${ }^{7}$ These intercepts are not included in the regression outputs below as all variables are demeaned and the "within transformation" is applied to multiple factors (Gaure, 2013).

${ }^{8}$ For all specifications, statistically significant (to the five percent level) Hausman test estimates suggest the random effects assumption is less likely to be supported by the data, thus supporting the use of a fixed effects framework.

${ }^{9}$ Interestingly, similarly to the conflict variable used in the present analysis, McGuirk and Burke use ACLED data to code output conflict, but rely on a different dataset to code factor conflict (2017, 11-12). 


\section{References}

Adano, W.R., T. Dietz, K. Witsenburg, and F. Zaal. 2012. "Climate change, violent conflict and local institutions in Kenya's drylands." Journal of Peace Research 49:65-80.

Adhvaryu, A., J. Fenske, G. Khanna, and A. Nyshadham. 2017. "Resources, Conflict, and Economic Development in Africa." A working paper. http://www-personal.umich.edu/ qkhanna/Conflict_Africa.pdf.

Angrist, J.D., and J.S. Pischke. 2009. Mostly Harmless Econometrics. Princeton, NJ: Princeton University Press.

Arellano, M. 2003. "Modelling optimal instrumental variables for dynamic panel data models." CEMFI Working Paper No. 0310. ftp://193.146.129.230/wp/03/0310.pdf.

Arias, M.A., A.M.I. Londoño, and A. Zambrano. 2017. "Agricultural Production Amid Conflict: Separating the Effects of Conflict into Shocks and Uncertainty." HiCN Working Paper 245. http://www.hicn.org/wordpress/wp-content/uploads/2012/06/ HiCN-WP-245.pdf.

Bannon, I., and P. Collier. 2003. Natural resources and Violent Conflict: Options and Actions. Washington, D.C.: World Bank.

Barrett, C.B. 2010. "Measuring Food Insecurity." Science 327:825-828.

Baumol, W.J. 2004. "Red-Queen games: arms races, rule of law and market economies." Journal of Evolutionary economics 14:237-247.

Bellemare, M.F. 2015. "Rising Food Prices, Food Price Volatility, and Social Unrest." American Journal of Agricultural Economy 97:1-21.

Blattman, C., and E. Miguel. 2010. "Civil War." Journal of Economic Literature 48:3-57.

Blundell, R., and S. Bond. 1998. "Initial conditions and moment restrictions in dynamic panel data models." Journal of econometrics 87:115-143.

Burke, M., E. Miguel, S. Satyanath, J. Dykema, and D. Lobell. 2009. "Warming Increases the Risk of War in Africa." PNAS 106:20670-20674.

Butler, C.K., and S. Gates. 2012. "African range wars: Climate, conflict, and property rights." Journal of Peace Research 49:23-34.

Carleton, T.A., and S.M. Hsiang. 2016. "Social and economic impacts of climate." Science 353:aad9837.

Conley, T.G., C.B. Hansen, and P.E. Rossi. 2012. "Plausibly exogenous." Review of Economics and Statistics 94:260-272.

Crost, B., and J.H. Felter. 2016. "Export Crops and Civil Conflict." ESOC Working Paper No. 4. https://esoc.princeton.edu/wp4. 
Dell, M., B.F. Jones, and B.A. Olken. 2014. "What do we learn from the weather? The new climate-economy literature." Journal of Economic Literature 52:740-798.

FAO. 2008. "Climate Change and Food Security: A Framework Document." Policy Paper, Food and Agriculture Organization of the United Nations. http://www.fao.org/ forestry/15538-079b31d45081fe9c3dbc6ff34de4807e4.pdf.

—. 2016. "Statistics Division, Food and Agricultural Organization of the United Nations." http://faostat3.fao.org/home/E.

Fearon, J.D., and D.D. Laitin. 2003. "Ethnicity, Insurgency, and Civil War." American Political Science Review 97:75-90.

Fjelde, H. 2015. "Farming or fighting? Agricultural price shocks and civil war in Africa." World Development 67:525-534.

Fjelde, H., and L. Hultman. 2014. "Weakening the Enemy: A Disaggregated Study of Violence against Civilians in Africa." Journal of Conflict Research 58:1230-1257.

Gaure, S. 2013. "Ife: Linear group fixed effects." The R Journal 5:104-117.

Guttman, N.B. 1999. "Accepting the standardized precipitation index: a calculation algorithm." JAWRA Journal of the American Water Resources Association 35:311-322.

Homer-Dixon, T.F. 1998. Environment, Scarcity, and Violence. New York, NY: Basic Books.

Jaafar, H.H., and E. Woertz. 2016. "Agriculture as a funding source of ISIS: A GIS and remote sensing analysis." Food Policy 64:14-25.

Kastner, T., M.J.I. Rivas, W. Koch, and S. Nonhebel. 2012. "Global changes in diets and the consequences for land requirements for food." Proceedings of the National Academy of Science 109:6868-6872.

Koren, O., and B.E. Bagozzi. 2016. "From Global to Local, Food Insecurity is Associated with Contemporary Armed Conflicts." Food Security 8:999-1010.

—. 2017. "Living Off The Land: The Connection between Cropland, Food Security, and Violence against Civilians." Journal of Peace Research 53:351-364.

Koren, O., and A. Sarbahi. Forthcoming. "State Capacity, Insurgency and Civil War: A Disaggregated Analysis."

Lybbert, T.J., C.B. Barrett, J.G. McPeak, and W.K. Luseno. 2007. "Bayesian herders: Updating of rainfall beliefs in response to external forecasts." World Development 35:480-497.

Marshall, M.G., T.R. Jaggers, and K. Gurr. 2013. "Polity iv project: Political regime characteristics and transitions, 1800-2012." Technical Report. http://www. systemicpeace. org/polity/polity4.htm. 
Maystadt, J.F., and O. Ecker. 2014. "Extreme Weather and Civil War: Does Drought Fuel Conflict in Somalia through Livestock Price Shocks?" American Journal of Agricultural Economy 96:1157-1182.

McGuirk, E., and M. Burke. 2017. "The Economic Origins of Conflict in Africa." National Bureau of Economic Research Paper No. w23056. http://www. nber .org/papers/w23056.

Messer, E. 2009. "Rising Food Prices, Social Mobilization, and Violence." NAPA Bulletin, pp. $12-22$.

Miguel, E., S. Satyanath, and E. Sergenti. 2004. "Economic Shocks and Civil Conflict: An Instrumental Variables Approach." Journal of Political Economy 112:725-753.

Monfreda, C., N. Ramankutty, and J.A. Foley. 2008. "Farming the planet: 2. Geographic distribution of crop areas, yields, physiological types, and net primary production in the year 2000." Global biogeochemical cycles 22.

Nordhaus, W.D. 2006. "Geography and macroeconomics: New data and new findings." Proceedings of the National Academy of Sciences 103:3150-3517.

Nunn, N., and N. Qian. 2014. "US food aid and civil conflict." The American Economic Review 104:1630-1666.

O'Loughlin, J., F.D.W. Witmer, A.M. Linke, A. Laing, A. Gettelman, , and J. Dudhia. 2012. "Climate variability and conflict risk in East Africa, 1990-2009." Proceedings of the National Academy of Science 109:18344-18349.

Raleigh, C., A. Linke, H. Hegre, and J. Karlsen. 2010. "Introducing ACLED: An Armed Conflict Location and Event Dataset." Journal of Peace Research 47:651-660.

Ramankutty, N., A. Evan, C. Monfreda, and J. Foley. 2008. "Farming the planet: 1. Geographic distribution of global agricultural lands in the year 2000." Global Biogeochem. Cycles 22:Article N. GB1003.

Ray, D.K., N. Ramankutty, N.D. Mueller, P.C. West, and J.A. Foley. 2012. "Recent patterns of crop yield growth, stagnation, and collapse." Nature Communications 3:Article N. 1293.

Rockmore, M. 2012. "Living within conflicts: risk of violence and livelihood portfolios." Working paper, HiCN Working Paper 121. http://www.hicn.org/wordpress/wp-content/ uploads/2012/06/HiCN-WP-121.pdf.

Roncoli, C., K. Ingram, and P. Kirshen. 2001. "The costs and risks of coping with drought: livelihood impacts and farmers' responses in Burkina Faso." Climate Research 19:119-132.

Roodman, D. 2009. "A note on the theme of too many instruments." Oxford Bulletin of Economics and statistics 71:135-158.

Ross, M.L. 2011. "Oil and Gas Data, 1932-2011." http://hdl.handle.net/1902.1/ 20369UNF : 5 : dc22RIDasveOTAJvwIjBTA==V2. 
Sachs, J., R. Remans, S. Smukler, L. Winowiecki, S.J. Andelman, K.G. Cassman, D. Castle, R. DeFries, G. Denning, J. Fanzo, et al. 2010. "Monitoring the world's agriculture." Nature 466:558-560.

Sarsons, H. 2015. "Rainfall and conflict: A cautionary tale." Journal of development Economics 115:62-72.

Stock, J.H., and M. Yogo. 2003. "Testing for Weak Instruments in Linear IV Regression." Working Paper, National Bureau of Economic Research. http: //scholar.harvard.edu/files/stock/files/testing_for_weak_instruments_ in_linear_iv_regression.pdf.

Toft, M.D. 2006. "Issue Indivisibility and Time Horizons as Rationalist Explanations for War." Security Studies 15:34-69.

Tollefsen, A. Forø, H. Strand, and H. Buhaug. 2012. "PRIO-GRID: A Unified Spatial Data Structure." Journal of Peace Research 49:363-374.

World Bank. 2015. World Development Indicators 2015. World Bank Publications.

Wucherpfennig, J., N.B. Weidman, L. Giardin, L.E. Cederman, and A. Wimmer. 2011. "Politically relevant ethnic groups across space and time: Introducing the GeoEPR dataset." Conflict Managment and Peace Science 20:1-15. 

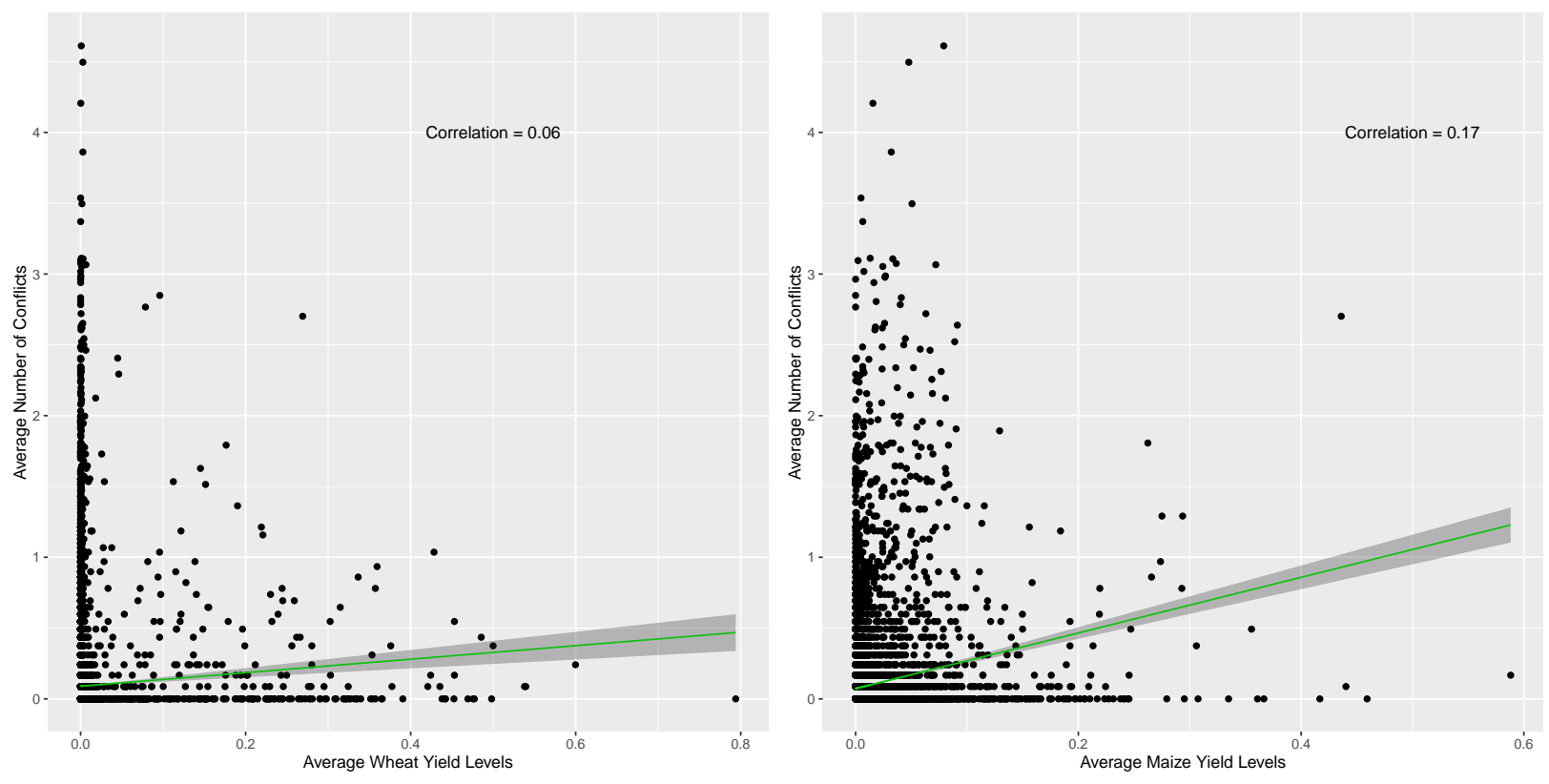

Figure 1: The linear correlation between annual wheat (left) and maize yields (right) and conflict by $0.5 \circ$ grids, 1998-2008. Conflict measures are presented in natural log form.
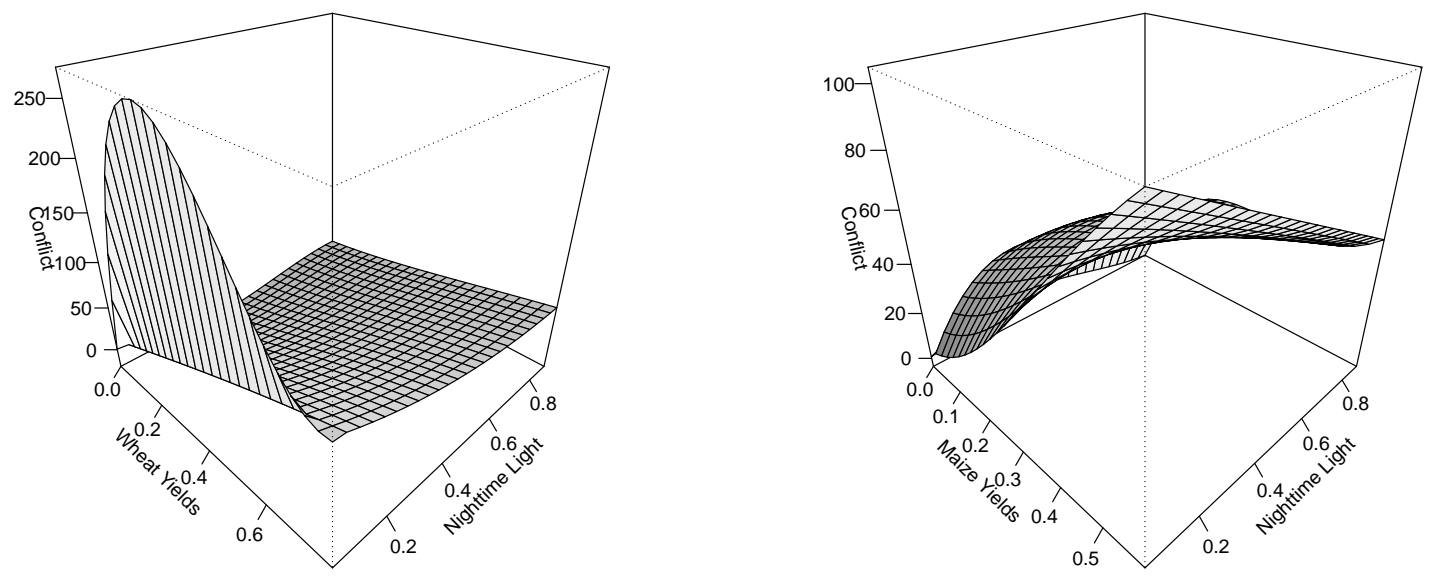

Figure 2: Nonparamteric regression plots of annual nighttime light emissions on violent conflict over the range of (left) wheat yields and (right) maize yields by grid cell in Africa, 1998-2008. 
Table 1: Summary Statistics of All Variables

\begin{tabular}{|c|c|c|c|c|c|}
\hline Variable & Minimum & Median & Mean & Max & $\mathrm{SD}$ \\
\hline \multicolumn{6}{|c|}{ Grid Cell Level Variables } \\
\hline Conflict & 0 & 0 & 0.228 & 334 & 2.854 \\
\hline Wheat yield & 0 & $2.63 \mathrm{e}-05$ & 0.009 & 0.930 & 0.047 \\
\hline Maize yield & 0 & 0.004 & 0.016 & 0.667 & 0.034 \\
\hline Drought & 0 & 0 & 0.229 & 2.5 & 0.654 \\
\hline Conflict (lag) & 0 & 0 & 0.182 & 334 & 2.523 \\
\hline Conflict (spatial) & 0 & 0 & 0.091 & 1 & 0.287 \\
\hline Population $^{1}$ & 0 & 9.721 & 9.369 & 16.268 & 2.263 \\
\hline Nighttime light & 0.021 & 0.034 & 0.040 & 0.941 & 0.032 \\
\hline Ethnic diversity & 0 & 1 & 1.325 & 7 & 1.177 \\
\hline Terr. change & 0 & 0 & 0.007 & 1 & 0.081 \\
\hline Temperature & 3.625 & 24.675 & 24.382 & 32.617 & 3.774 \\
\hline Temperature (lag) & 3.625 & 24.658 & 24.364 & 32.617 & 3.778 \\
\hline Wheat yield (lag) & 0 & $2.58 \mathrm{e}-05$ & 0.009 & 0.930 & 0.047 \\
\hline Maize yield (lag) & 0 & 0.004 & 0.016 & 0.642 & 0.034 \\
\hline Violent conflict & 0 & 0 & 0.069 & 220 & 1.209 \\
\hline Violent conflict (lag) & 0 & 0 & 0.055 & 220 & 1.038 \\
\hline Military conflict & 0 & 0 & 0.103 & 286 & 1.726 \\
\hline Military conflict (lag) & 0 & 0 & 0.081 & 286 & 1.550 \\
\hline Conflict $^{1}$ & 0 & 0 & 0.062 & 5.814 & 0.320 \\
\hline Conflict $(\mathrm{lag})^{1}$ & 0 & 0 & 0.047 & 5.814 & 0.289 \\
\hline Any drought & 0 & 0 & 0.123 & 1 & 0.328 \\
\hline Severe drought & 0 & 0 & 0.088 & 1 & 0.283 \\
\hline Extreme drought & 0 & 0 & 0.062 & 1 & 0.241 \\
\hline \multicolumn{6}{|l|}{ Country Level Variables } \\
\hline Democracy & -9 & 0 & 0.214 & 10 & 5.084 \\
\hline GDP per capita ${ }^{1}$ & 5.517 & 7.350 & 7.547 & 10.341 & 1.106 \\
\hline Food imports (\%) & 0.474 & 16.493 & 17.313 & 62.416 & 7.510 \\
\hline Agricultural imports (\%) & 0.146 & 1.175 & 1.870 & 42.322 & 3.040 \\
\hline${\text { Foreign } \text { aid }^{1}}$ & 15.713 & 20.040 & 19.947 & 23.240 & 1.269 \\
\hline Oil production ${ }^{1}$ & 0 & 13.592 & 9.170 & 18.690 & 8.075 \\
\hline Gas production ${ }^{1}$ & 0 & 0 & 1.663 & 7.192 & 2.369 \\
\hline Military expenditure $e^{1,2}$ & 0 & 12.612 & 12.536 & 15.350 & 1.645 \\
\hline Cereal prod. index & 0.015 & 91.957 & 99.050 & 882.89 & 57.648 \\
\hline Meat prod. index & 0.032 & 91.620 & 93.835 & 737.38 & 52.157 \\
\hline
\end{tabular}

${ }^{2}$ This variable is only available for the years 1998-2007 
Table 2: OLS regression models for total number of conflict events per grid cell, 1998-2008

\begin{tabular}{|c|c|c|c|c|}
\hline \multirow{2}{*}{ Variable } & \multicolumn{2}{|c|}{ Wheat Yield } & \multicolumn{2}{|c|}{ Maize Yield } \\
\hline & 1) Baseline & 2) Full & 3) Baseline & 4) Full \\
\hline Wheat yield & $\begin{array}{l}-0.517 \\
(0.464)\end{array}$ & $\begin{array}{l}-0.528 \\
(0.472)\end{array}$ & 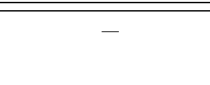 & - \\
\hline Maize yield & - & - & $\begin{array}{c}-3.749^{* *} \\
(1.682)\end{array}$ & $\begin{array}{c}-3.111^{* * *} \\
(1.188)\end{array}$ \\
\hline Conflict (lag) & - & $\begin{array}{c}0.202^{* *} \\
(0.084)\end{array}$ & - & $\begin{array}{c}0.202^{* *} \\
(0.084)\end{array}$ \\
\hline Conflict (spatial) & - & $\begin{array}{c}0.337^{* * *} \\
(0.083)\end{array}$ & - & $\begin{array}{c}0.336^{* * *} \\
(0.083)\end{array}$ \\
\hline Population $^{1}$ & - & $\begin{array}{c}-0.663^{* * *} \\
(0.190)\end{array}$ & - & $\begin{array}{c}-0.633^{* * * *} \\
(0.187)\end{array}$ \\
\hline Democracy & - & $\begin{array}{c}-0.022^{* *} \\
(0.010)\end{array}$ & - & $\begin{array}{c}-0.022^{* *} \\
(0.010)\end{array}$ \\
\hline$G D P$ per capita ${ }^{1}$ & - & $\begin{array}{c}0.019 \\
(0.173)\end{array}$ & - & $\begin{array}{c}0.024 \\
(0.172)\end{array}$ \\
\hline Observations & 72,213 & 68,204 & 72,213 & 68,204 \\
\hline $\mathrm{R}^{2}$ & 0.454 & 0.429 & 0.454 & 0.429 \\
\hline Adjusted $\mathrm{R}^{2}$ & 0.400 & 0.370 & 0.400 & 0.370 \\
\hline
\end{tabular}

Cell values are OLS regression coefficient estimates with standard errors clustered by grid-cell in parentheses. Grid cell and year fixed effects included in each regression though not reported here.

${ }^{1}$ Natural log 
Table 3: IV regression models for total number of conflict events per grid cell, 1998-2008

\begin{tabular}{|c|c|c|c|c|}
\hline \multirow[t]{2}{*}{ Variable } & \multicolumn{2}{|c|}{ Wheat Yield } & \multicolumn{2}{|c|}{ Maize Yield } \\
\hline & 1E) Baseline & 2E) Full & 3E) Baseline & 4E) Full \\
\hline Wheat yield & $\begin{array}{c}75.13^{* * *} \\
(24.35)\end{array}$ & $\begin{array}{c}83.53^{* * *} \\
(26.05)\end{array}$ & ב- & - \\
\hline Maize yield & - & - & $\begin{array}{c}184.40^{* * *} \\
(58.90)\end{array}$ & $\begin{array}{c}204.74 * * * \\
(62.77)\end{array}$ \\
\hline Conflict (lag) & - & $\begin{array}{c}0.201^{* *} \\
(0.084)\end{array}$ & - & $\begin{array}{c}0.206^{* *} \\
(0.084)\end{array}$ \\
\hline Conflict (spatial) & - & $\begin{array}{c}0.343^{* * *} \\
(0.087)\end{array}$ & - & $\begin{array}{c}0.436^{* * *} \\
(0.110)\end{array}$ \\
\hline Population $^{1}$ & - & $\begin{array}{c}-0.877^{* * *} \\
(0.239)\end{array}$ & - & $\begin{array}{c}-2.762^{* * *} \\
(0.798)\end{array}$ \\
\hline Democracy & - & $\begin{array}{c}-0.032^{* * *} \\
(0.011)\end{array}$ & - & $\begin{array}{c}0.007 \\
(0.013)\end{array}$ \\
\hline GDP per capita ${ }^{1}$ & - & $\begin{array}{l}-0.048 \\
(0.180)\end{array}$ & - & $\begin{array}{l}-0.336 \\
(0.246)\end{array}$ \\
\hline Observations & 72,169 & 68,160 & 72,169 & 68,160 \\
\hline Endogenous variables test & $9.520 * * *$ & $10.28^{* * *}$ & $9.809^{* * *}$ & $10.64 * * *$ \\
\hline Weak instrument F-statistic (clustered SEs) & 50.22 & 8.372 & 51.48 & 8.955 \\
\hline Weak instrument F-statistic (i.i.d. SEs) & 191.39 & 31.84 & 88.74 & 15.26 \\
\hline $\mathrm{R}^{2}$ & 0.414 & 0.351 & 0.366 & 0.264 \\
\hline Adjusted $\mathrm{R}^{2}$ & 0.354 & 0.284 & 0.301 & 0.187 \\
\hline
\end{tabular}

Cell values are IV regression coefficient estimates with standard errors clustered by grid-cell in parentheses.

Grid cell and year fixed effects included in each regression though not reported here. The variables wheat yield and maize yield were instrumented using drought.

${ }^{1}$ Natural log 
Table 4: IV regression models for total number of conflict events per grid cell, LTZ simulations

\begin{tabular}{|c|c|c|c|c|}
\hline \multirow[t]{2}{*}{ Variable } & \multicolumn{2}{|c|}{ Wheat Yield } & \multicolumn{2}{|c|}{ Maize Yield } \\
\hline & 5) Baseline & 6) Full & 7) Baseline & 8) Full \\
\hline Wheat yield & $\begin{array}{c}261.17^{* * *} \\
(77.48)\end{array}$ & $\begin{array}{c}150.19 * * \\
(59.96)\end{array}$ & - & - \\
\hline Maize yield & - & - & $\begin{array}{c}312.11^{* * *} \\
(90.24)\end{array}$ & $\begin{array}{c}210.58^{* *} \\
(81.22)\end{array}$ \\
\hline Population $^{1}$ & $\begin{array}{c}1.259^{* * *} \\
(0.326)\end{array}$ & $\begin{array}{c}-0.752^{*} \\
(0.383)\end{array}$ & $\begin{array}{c}0.541 \\
(0.474)\end{array}$ & $\begin{array}{c}-1.285^{* *} \\
(0.595)\end{array}$ \\
\hline Conflict (spatial) & - & $\begin{array}{c}36.19^{* * *} \\
(3.327)\end{array}$ & - & $\begin{array}{c}35.37^{* * * *} \\
(3.139)\end{array}$ \\
\hline Democracy & - & $\begin{array}{c}0.406^{* * *} \\
(0.128)\end{array}$ & - & $\begin{array}{l}-0.112 \\
(0.086)\end{array}$ \\
\hline GDP per capita ${ }^{1}$ & - & $\begin{array}{c}-2.184^{* *} \\
(0.840)\end{array}$ & - & $\begin{array}{l}-0.644^{*} \\
(0.340)\end{array}$ \\
\hline Constant & $\begin{array}{c}-11.85^{* * *} \\
(3.008)\end{array}$ & $\begin{array}{c}20.22^{* *} \\
(9.171)\end{array}$ & $\begin{array}{c}-6.973^{*} \\
(3.878)\end{array}$ & $\begin{array}{l}13.65^{*} \\
(7.167)\end{array}$ \\
\hline Observations & 6,680 & 6,429 & 6,680 & 6,429 \\
\hline Endogenous variables test & $11.69^{* * *}$ & $7.437 * * *$ & $12.33^{* * *}$ & $7.174^{* * *}$ \\
\hline Weak instrument F-statistic (clustered SEs) & 22.303 & 9.404 & 25.56 & 7.284 \\
\hline Weak instrument F-statistic (i.i.d. SEs) & 11.12 & 5.931 & 19.59 & 5.581 \\
\hline $\mathrm{R}^{2}$ & -0.191 & 0.063 & -0.101 & 0.069 \\
\hline Adjusted $\mathrm{R}^{2}$ & -0.192 & 0.062 & -0.1012 & 0.068 \\
\hline
\end{tabular}

Cell values are IV regression coefficient estimates with standard errors clustered by grid-cell in parentheses. The variables wheat yield and maize yield were instrumented using a collapsed binary version of drought.

${ }^{1}$ Natural $\log$ 
Table 5: GMM IV regression models for total number of conflict events per grid cell, 19982008

\begin{tabular}{lcc||cc}
\hline \hline Variable & \multicolumn{2}{c}{ Wheat Yield } & \multicolumn{2}{c}{ Maize Yield } \\
& 9) Baseline & 10) Full & 11) Baseline & 12) Full \\
\hline \hline Wheat yield & $0.610^{* * *}$ & $0.231^{* *}$ & - & - \\
& $(0.174)$ & $(0.108)$ & & \\
Maize yield & - & - & $2.257^{* * *}$ & $0.309^{*}$ \\
& & & $(0.530)$ & $(0.165)$ \\
Conflict (lag) & $0.382^{* * *}$ & $0.781^{* * *}$ & $0.381^{* * *}$ & $0.780^{* * *}$ \\
& $(0.090)$ & $(0.087)$ & $(0.089)$ & $(0.087)$ \\
Conflict (spatial) & - & $-0.223^{*}$ & - & $-0.220^{*}$ \\
& & $(0.127)$ & & $(0.127)$ \\
Population ${ }^{1}$ & - & -0.0003 & - & -0.001 \\
& & $(0.002)$ & & $(0.002)$ \\
Democracy & - & 0.001 & - & -0.0001 \\
& - & $(0.001)$ & $(0.001)$ & \\
GDP per capita & & 0.002 & - & 0.003 \\
& - & $(0.003)$ & & $(0.003)$ \\
\hline Observations & 72,169 & 68,160 & 72,169 & 68,160 \\
Sargan test & $73.69^{* * *}$ & $612.47^{* * *}$ & $75.436^{* * *}$ & $613.03^{* * *}$ \\
DF & $(39)$ & $(43)$ & $(39)$ & $(43)$ \\
$\mathrm{R}^{2}$ & 0.082 & 0.088 & 0.083 & 0.088 \\
\hline \hline
\end{tabular}

Not $\overline{\overline{e:} \text { *indicates } p<0.1 ;{ }^{* *} \text { indicates } p<0.05 ; * * * \text { indicates } p<0.01 \text { (two-tail test). }}$.

Cell values are IV regression coefficient estimates with robust standard errors in parentheses. GMM instruments for all models are the $t-4$ and beyond lags of conflict.

${ }^{1}$ Natural $\log$ 


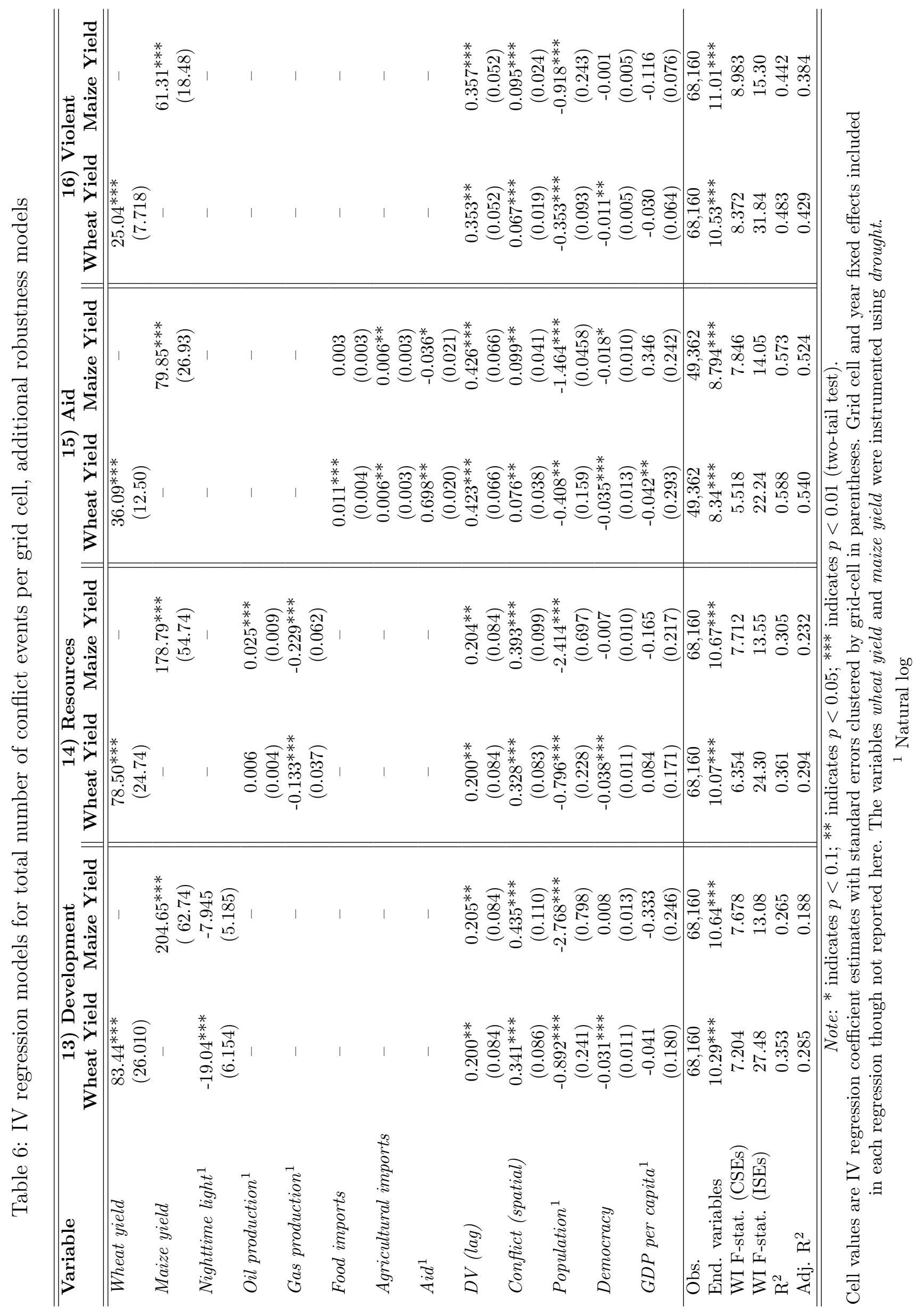




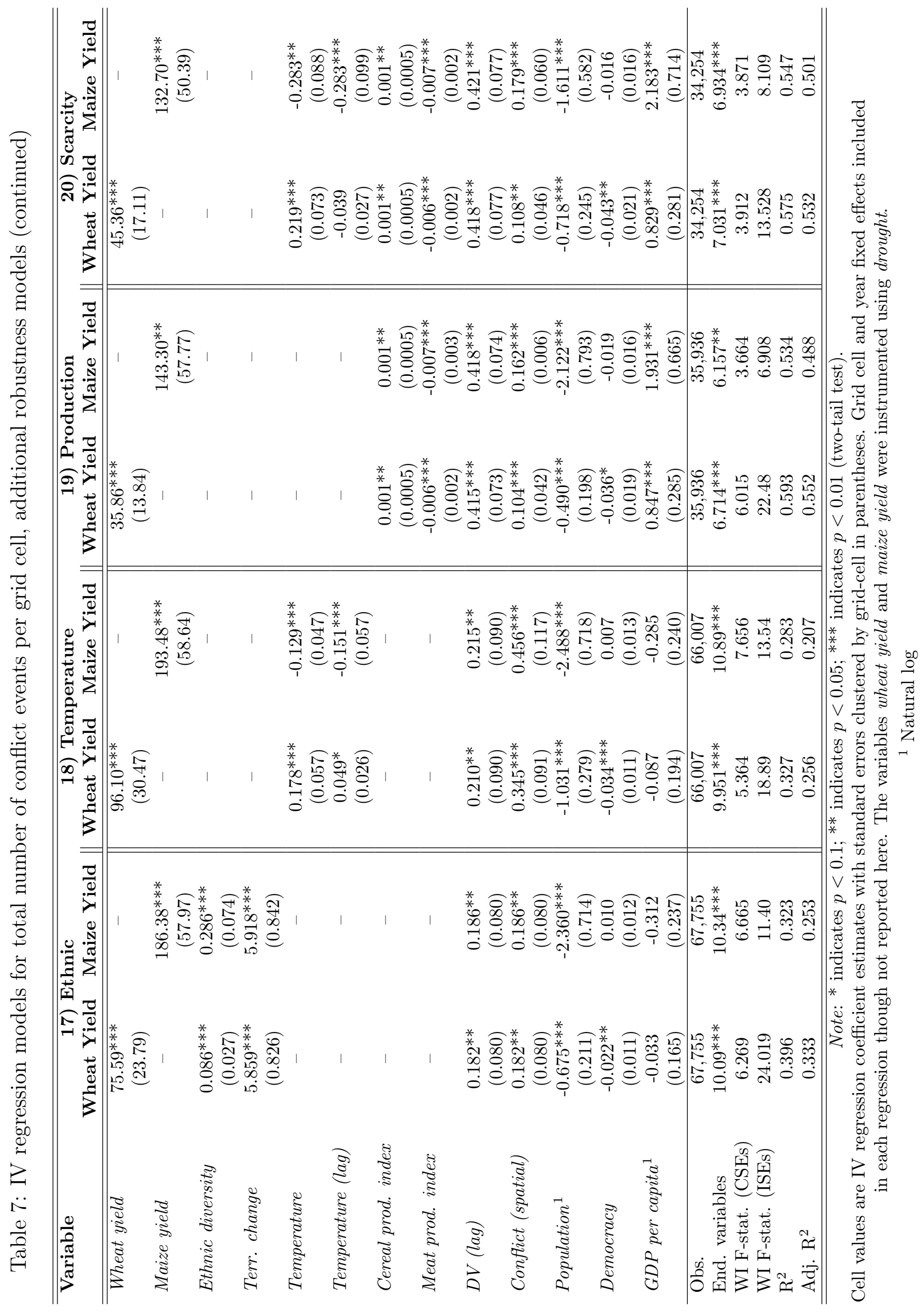




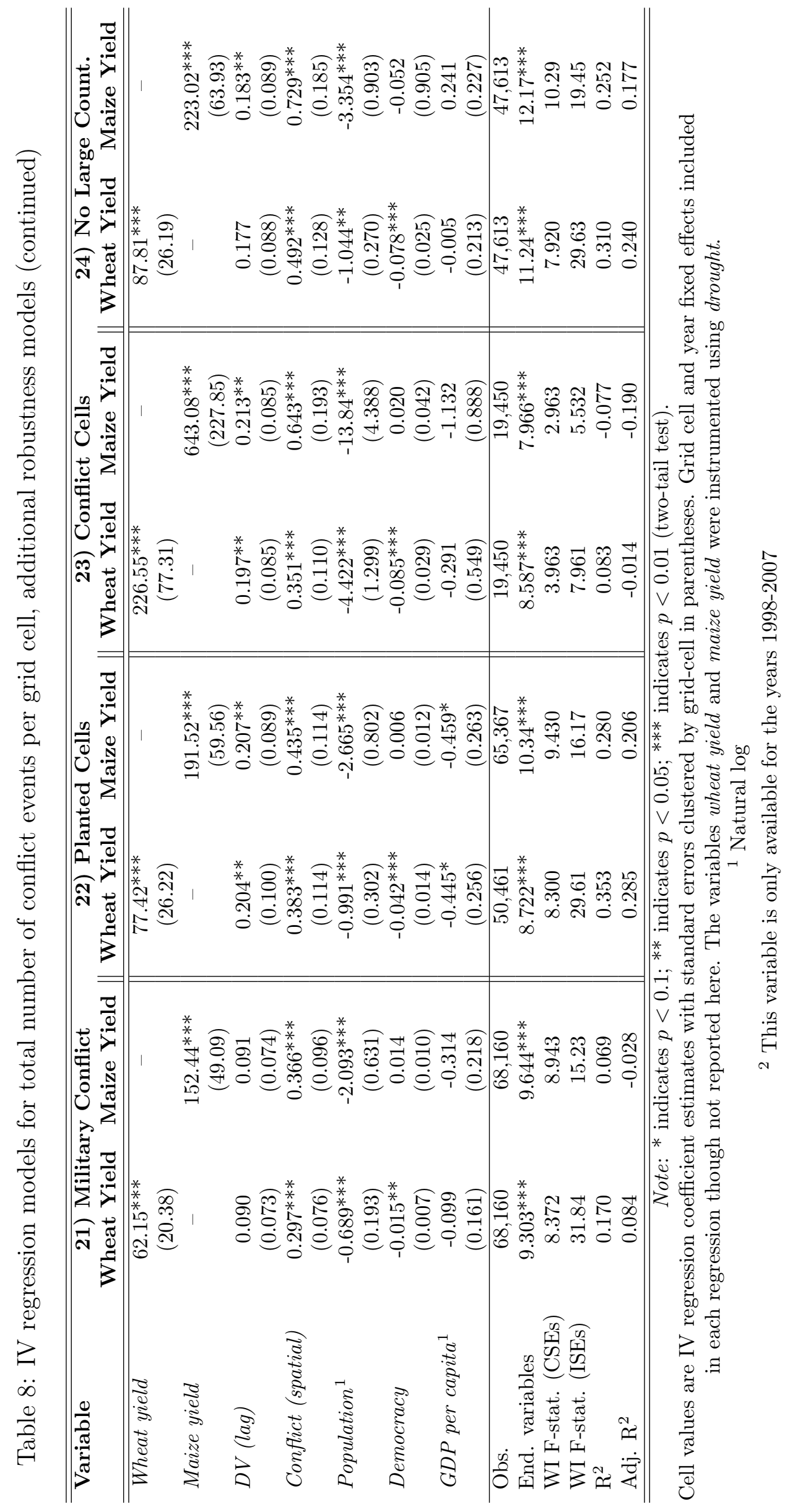




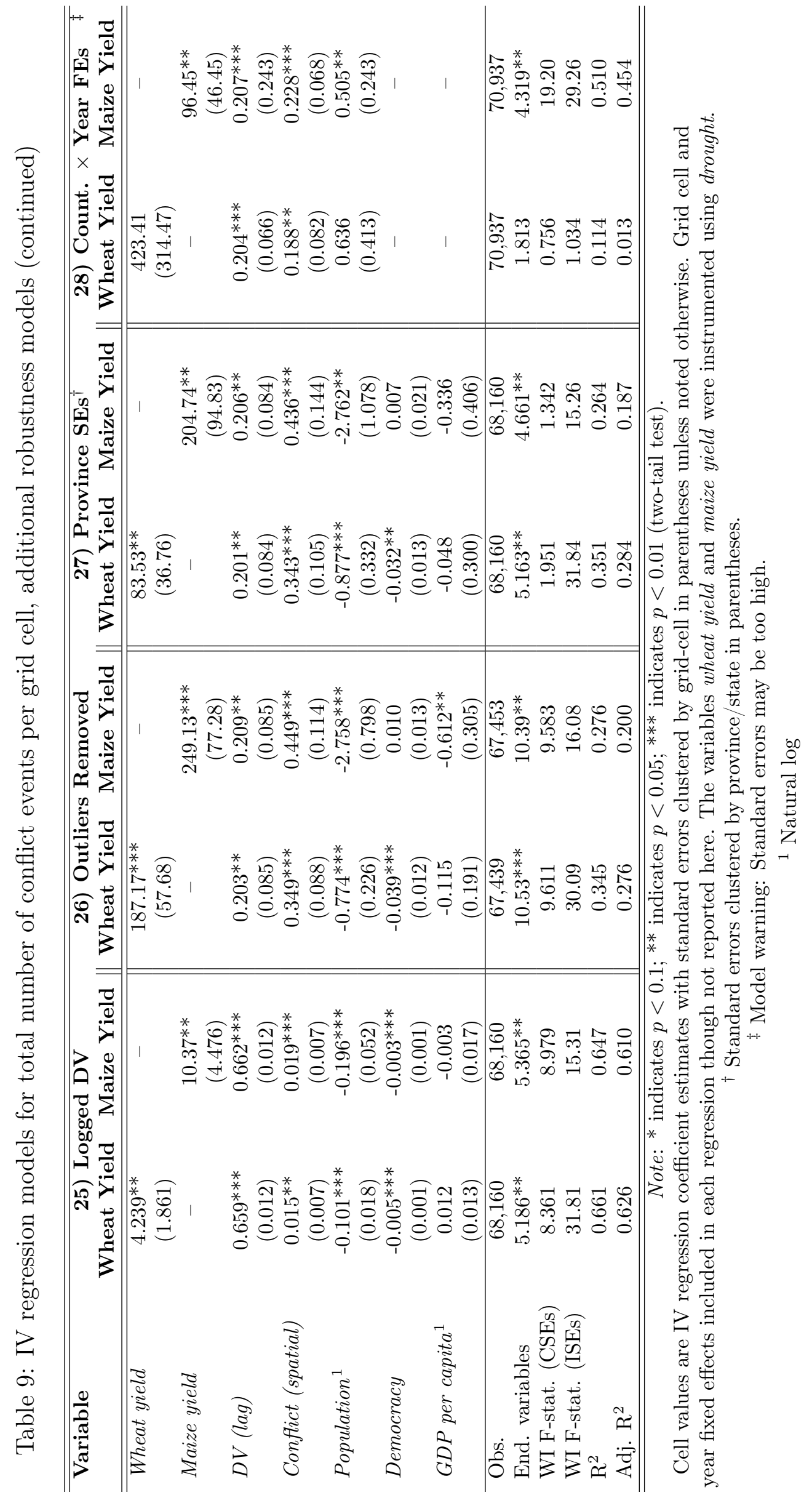




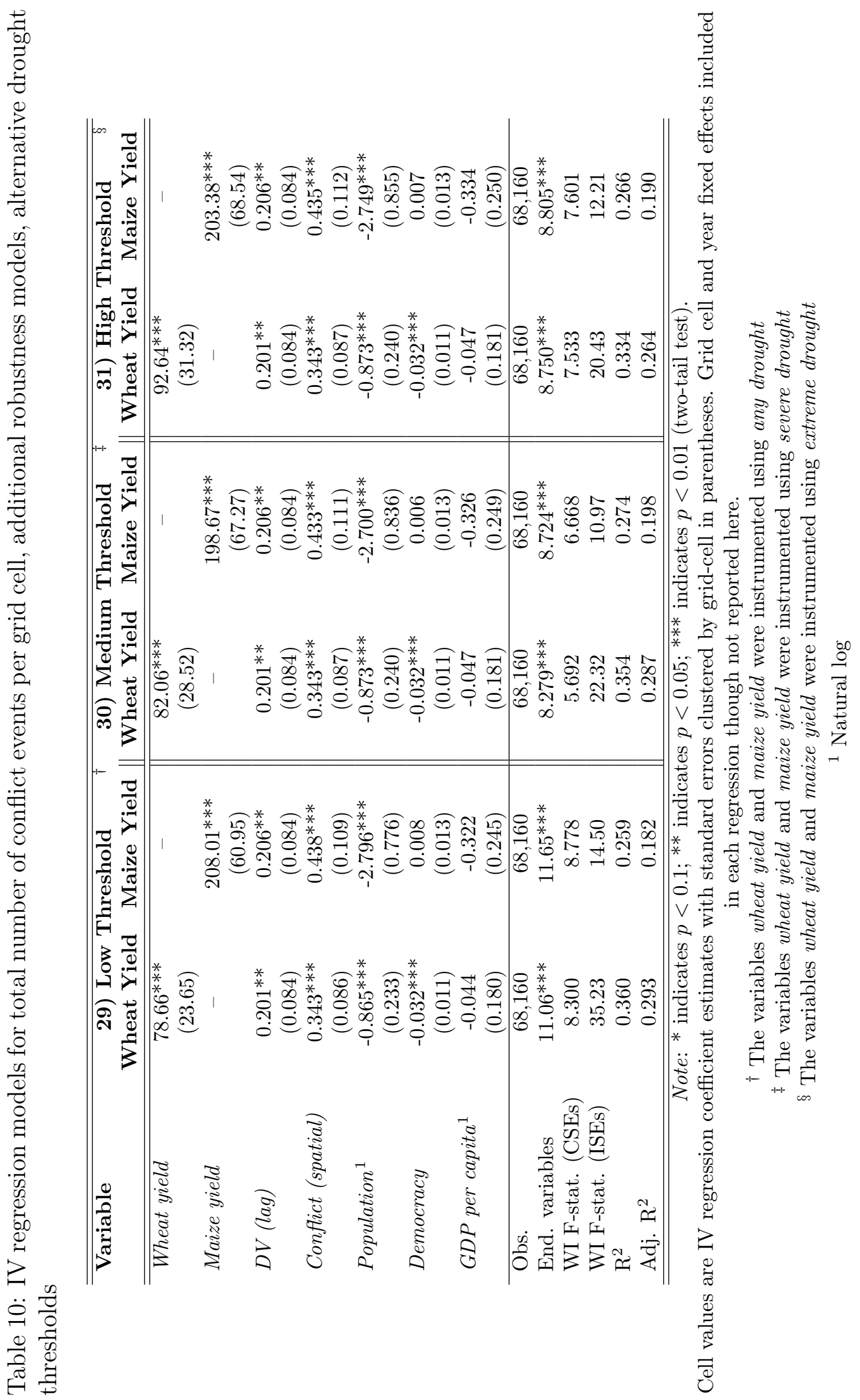

